\title{
A 60-year ice-core record of regional climate from Adélie Land, coastal Antarctica
}

\author{
Sentia Goursaud ${ }^{1,2,3}$, Valérie Masson-Delmotte ${ }^{1}$, Vincent Favier $^{2,3}$, Susanne Preunkert ${ }^{2,3}$, Michel Fily ${ }^{2,3}$, \\ Hubert Gallée $^{2,3}$, Bruno Jourdain ${ }^{2,3}$, Michel Legrand ${ }^{2,3}$, Olivier Magand ${ }^{2,3}$, Bénédicte Minster ${ }^{1}$, and Martin Werner ${ }^{4}$ \\ ${ }^{1}$ LSCE, UMR CEA-CNRS-UVSQ 8212-IPSL, Université Paris Saclay, Gif-sur-Yvette, France \\ ${ }^{2}$ Univ. Grenoble Alpes, CNRS, IRD, IGE, 38000 Grenoble, France \\ ${ }^{3}$ CNRS, Laboratoire de Glaciologie et Géophysique de l'Environnement (LGGE), 38041 Grenoble, France \\ ${ }^{4}$ Alfred Wegener Institute for Polar and Marine Research (AWI), Bremerhaven, Germany
}

Correspondence to: Sentia Goursaud (sentia.goursaud@1sce.ipsl.fr)

Received: 15 July 2016 - Published in The Cryosphere Discuss.: 8 September 2016

Revised: 7 December 2016 - Accepted: 26 December 2016 - Published: 1 February 2017

\begin{abstract}
A $22.4 \mathrm{~m}$-long shallow firn core was extracted during the 2006/2007 field season from coastal Adélie Land. Annual layer counting based on subannual analyses of $\delta^{18} \mathrm{O}$ and major chemical components was combined with 5 reference years associated with nuclear tests and non-retreat of summer sea ice to build the initial ice-core chronology (19462006), stressing uncertain counting for 8 years. We focus here on the resulting $\delta^{18} \mathrm{O}$ and accumulation records. With an average value of $21.8 \pm 6.9 \mathrm{~cm}^{\text {w.e. }} \mathrm{yr}^{-1}$, local accumulation shows multi-decadal variations peaking in the $1980 \mathrm{~s}$, but no long-term trend. Similar results are obtained for $\delta^{18} \mathrm{O}$, also characterised by a remarkably low and variable amplitude of the seasonal cycle. The ice-core records are compared with regional records of temperature, stake area accumulation measurements and variations in sea-ice extent, and outputs from two models nudged to ERA (European Reanalysis) atmospheric reanalyses: the high-resolution atmospheric general circulation model (AGCM), including stable water isotopes ECHAM5-wiso (European Centre Hamburg model), and the regional atmospheric model Modèle Atmosphérique Régional ( AR). A significant linear correlation is identified between decadal variations in $\delta^{18} \mathrm{O}$ and regional temperature. No significant relationship appears with regional sea-ice extent. A weak and significant correlation appears with Dumont d'Urville wind speed, increasing after 1979. The model-data comparison highlights the inadequacy of ECHAM5-wiso simulations prior to 1979, possibly due to the lack of data assimilation to constrain atmospheric reanalyses. Systematic biases are identified in the ECHAM5-wiso
\end{abstract}

simulation, such as an overestimation of the mean accumulation rate and its interannual variability, a strong cold bias and an underestimation of the mean $\delta^{18} \mathrm{O}$ value and its interannual variability. As a result, relationships between simulated $\delta^{18} \mathrm{O}$ and temperature are weaker than observed. Such systematic precipitation and temperature biases are not displayed by MAR, suggesting that the model resolution plays a key role along the Antarctic ice sheet coastal topography. Interannual variations in ECHAM5-wiso temperature and precipitation accurately capture signals from meteorological data and stake observations and are used to refine the initial ice-core chronology within 2 years. After this adjustment, remarkable positive (negative) $\delta^{18} \mathrm{O}$ anomalies are identified in the ice-core record and the ECHAM5-wiso simulation in 1986 and 2002 (1998-1999), respectively. Despite uncertainties associated with post-deposition processes and signal-to-noise issues, in one single coastal ice-core record, we conclude that the S1C1 core can correctly capture major annual anomalies in $\delta^{18} \mathrm{O}$ as well as multi-decadal variations. These findings highlight the importance of improving the network of coastal high-resolution ice-core records, and stress the skills and limitations of atmospheric models for accumulation and $\delta^{18} \mathrm{O}$ in coastal Antarctic areas. This is particularly important for the overall East Antarctic ice sheet mass balance. 


\section{Introduction}

Deep ice cores from coastal Antarctic areas are crucial for retrieving highly resolved, multi-millennial records, a priority of the International Partnership for Ice Core Science within the Past Global Changes 2k project (PAGES 2k Consortium, 2013). Obtaining highly resolved records spanning the last decades is therefore a prerequisite for identifying the potential of a given site. Moreover, climate variability of the last decades in Antarctica remains poorly documented and understood (e.g. Jones et al., 2016). This is particularly the case in coastal Antarctic areas, which play a key role for the overall Antarctic mass balance (Agosta et al., 2013; Palerme et al., 2016), with relevance for global sea level (Church et al., 2013). Finally, field data are needed to assess the validity of climate models for multi-decadal variability and change in coastal Antarctic temperature and mass balance (Krinner et al., 2007).

Here, we focus on coastal Adélie Land (Fig. 1), an area where regional climate is marked by the interplay of katabatic winds accelerating downslope from the Antarctic interior to the coast (Périard and Pettré, 1993), large seasonal variations in sea-ice extent (König-Langlo et al., 1998; Simmonds and Jacka, 1995) and its proximity to the circumpolar storm track (Jones and Simmonds, 1993). These features lead to dominant southerly $\left(160 \pm 20^{\circ}\right)$ intense katabatic winds (Wendler et al., 1997). During summer open sea conditions, a reverse pattern of wind direction can occur, associated with sea breezes. At the Dumont d'Urville station (hereafter DDU), Périard and Pettré (1993) reported an average wind speed of $10 \mathrm{~m} \mathrm{~s}^{-1}$, as well as events when wind speeds exceed $20 \mathrm{~m} \mathrm{~s}^{-1}$ during several days (with an observed local maximum wind speed at $90 \mathrm{~m} \mathrm{~s}^{-1}$ ). The region is therefore marked by sastrugi formed by snow erosion and redeposition, The resulting high spatial variability in accumulation challenges the climatic interpretation of a single ice-core record, especially for accumulation rates lower than $20 \mathrm{~cm}$ w.e. $\mathrm{yr}^{-1}$ (Frezzotti et al., 2007). Knowledge of Adélie Land climate variability therefore requires a spatial network of field data.

Multi-decadal climate variability in this region has been documented since 1958 from DDU meteorological measurements, and since 1979 from sea-ice remote sensing. Only a few shallow ice cores were drilled near DDU (MassonDelmotte et al., 2008), and none were dated (Jean Jouzel, personal communication, 2016), preventing any comparison of ice-core records with meteorological measurements.

In the framework of the International TASTEIDEA/VANISH programmes (Trans-Antarctic Scientific Traverse Expeditions - Ice Divide of East Antarctica), a $22.4 \mathrm{~m}$-long shallow firn core (named S1C1) was extracted in January 2007 from the Adélie Land sector $\left(67.71^{\circ} \mathrm{S}\right.$, $139.83^{\circ} \mathrm{E}, 279 \mathrm{~m}$ a.s.1.) (Fig. 1). The core was collected close to a stake network, which provides records of accumulation spatio-temporal variability from 1971 to 2015 (Favier et al., 2013).

Following the classical approach for other coastal Antarctic areas, the chronology of the $\mathrm{S} 1 \mathrm{C} 1$ core is established through the annual layer counting of seasonal cycles in chemical species, water isotopes records and absolute horizons (e.g. Graf et al., 1991; Mulvaney et al., 2002). This task was feasible thanks to multi-year aerosol monitoring at subseasonal scale at DDU, providing detailed information on the seasonal cycle of aerosols. However, no such monitoring is available for precipitation isotopic composition at this site. Indeed, very few multi-year direct records of snowfall isotopic composition are available from Antarctica (Fujita and Abe, 2006; Landais et al., 2012; Schlosser et al., 2008, 2016; Stenni et al., 2016), and emerging records of water vapour isotopic composition only span 1 month (Casado et al., 2016; Ritter et al., 2016). We therefore investigated seasonal variations in precipitation isotopic composition from a simulation performed with the isotopically enabled ECHAM5-wiso (European Centre Hamburg model) AGCM (atmospheric general circulation model, hereafter ECHAM5-wiso; Roeckner et al., 2003; Werner et al., 2011) nudged to ERA40 (European Reanalysis; Uppala et al., 2005) and ERA-Interim atmospheric reanalyses (Dee et al., 2011). This high-resolution model was chosen for its good skills with respect to the present-day spatial distribution of stable water isotopes and mass balance in Antarctica (MassonDelmotte et al., 2008; Werner et al., 2011). The 50-year long simulation is used to identify uncertainties associated with annual layer counting based on the seasonal cycle in precipitation $\delta^{18} \mathrm{O}$. On the contrary, the ice-core record and the stake area network will allow for an assessment of the skills of this simulation in coastal Adélie Land. These model-data were further expanded through investigation of recent mass balance and temperature variations from the regional atmospheric model MAR (Modèle Atmosphérique Régional; Gallée and Schayes, 1994).

Section 2 describes the material and methods underlying this study, including our new measurements, the methodology for the annual layer counting, as well as the regional instrumental (near-surface air temperature, wind speed and stake area measurements) and remote sensing (sea-ice extent) datasets and the simulations performed with these two atmospheric models. Section 3 reports our results. In Sect. 4 , we discuss our new ice-core records and compare $\delta^{18} \mathrm{O}$ and accumulation records with local to regional climate information as well as atmospheric model outputs. We summarise our main findings and suggest future research directions in our conclusions (Sect. 5).

\section{Material and method}

Here, we briefly describe the ice-core sampling, the chemical and isotopic analyses, the density measurements and the 

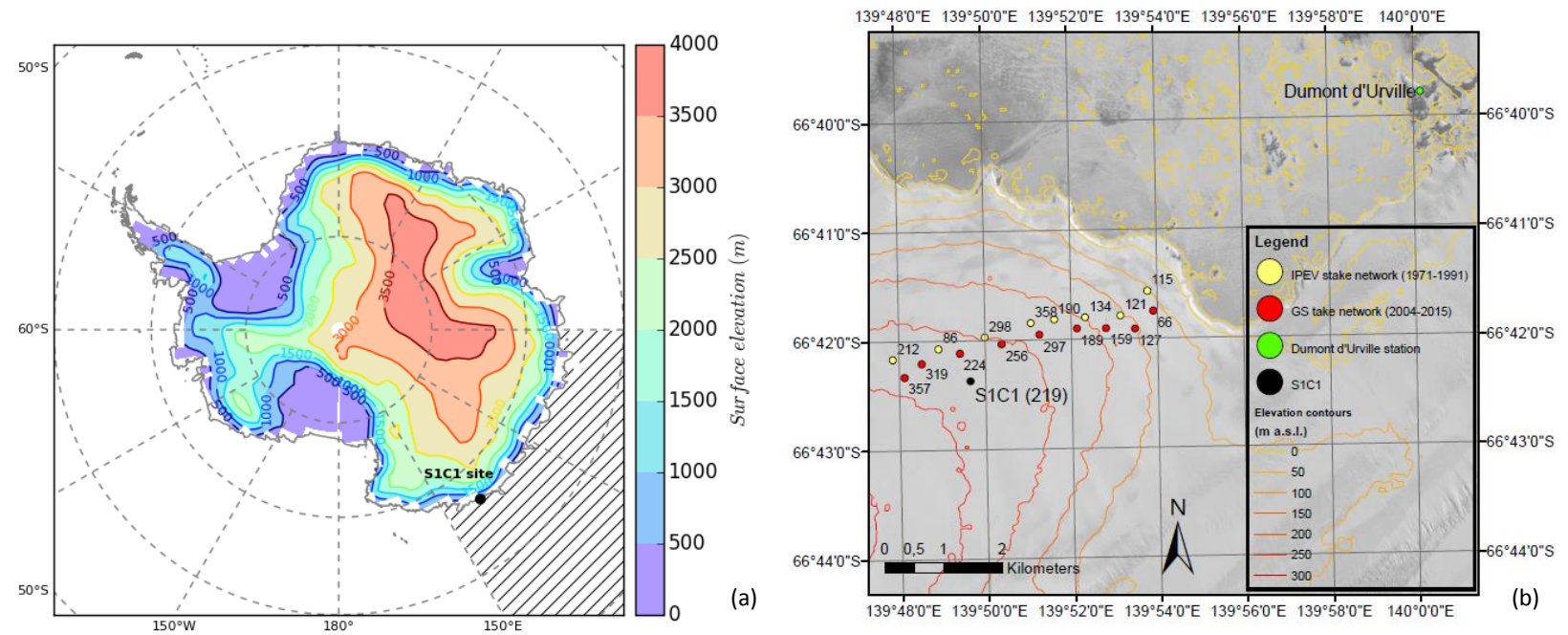

Figure 1. Maps showing the areas of interest with (a) a map of Antarctica representing the local topography (contours), the location of the S1C1 drilling site and the area used to extract regional sea-ice extent from the Nimbus-7 Scanning Multichannel Microwave Radiometer (SMMR) and Defense Meteorological Satellite Program Special Sensor Microwave/Imagers - Special Sensor Microwave Image/Sounder (DMSP SSM/I-SSMIS) passive microwave data (hatched area), and (b) an orientation map showing stake networks around S1C1 drilling site. Data from 1971 to 1991 were measured by IPEV, whereas data from 2004 to 2015 were measured in the framework of GLACIOCLIMSAMBA (GS) observatory. Elevation lines are from the digital elevation model by Korona et al. (2009), which was computed from SPOT5 images obtained during the fourth International Polar Year (2007-2009). The SPOT5 image is also included as a background map. Labels are mean accumulation values at each stake computed over the period with measurements.

dating methodology. We then introduce the regional climate datasets used for statistical analyses, as well as the atmospheric simulations used for model-data comparisons.

\subsection{Field work and ice-core sampling}

The field campaign was conducted from the 16 to the 26 January 2007 in Adélie Land by a French joint LGGE (Laboratoire de Glaciologie et Géophysique de l'Environnement) and IPEV (Institut Français Polaire Paul-Emile Victor) expedition. Several shallow firn cores were drilled along a transect between the Italian-French Cap Prud'Homme station at sea level and the D47 point, located around $1600 \mathrm{~m}$ a.s.l. and approximately $100 \mathrm{~km}$ from the coast. This round-trip traverse was part of the ANR-VANISH (Vulnerability of the Antarctic Ice-Sheet) and IPEV-TASTE-IDEA (Trans-Antarctic Scientific Traverses Expeditions - Ice Divide of East Antarctica) scientific programmes. The scientific aim of the programmes was to obtain new firn core records and ground-penetrating radar measurements to improve knowledge of coastal East Antarctic accumulation.

The present paper is focused on one ice core drilled at the S1C1 site $\left(66.71^{\circ} \mathrm{S}, 139.83^{\circ} \mathrm{E}, 279 \mathrm{~m}\right.$ a.s.l.), the closest sampling site to the coast and the French Dumont D'Urville station (Fig. 1). At this site, the measured temperature of the firn was $-13.1 \pm 0.5^{\circ} \mathrm{C}$ at $10 \mathrm{~m}$ depth. Data obtained over 3 days at $25 \mathrm{~cm}$ depth show a mean value of $-5.0^{\circ} \mathrm{C}$. At DDU and Dome C, July 2007 temperatures were close to the climatological average conditions from the period 1995-2015. As a result, our measurements from summer 2007 are assumed to be representative of average summer conditions. Such negative near-surface air summer temperature ensures preservation of snow signals (e.g. stable water isotopes, chemical species).

A portable solar-powered electromechanical drilling system was used to extract the $22.4 \mathrm{~m}$ long and $58 \mathrm{~mm}$ diameter firn core (Ginot et al., 2002; O. Magand, personal communication, 2016; Verfaillie et al., 2012). The recovered core pieces were sealed in polyethylene bags in the field, stored in clean isothermal boxes and transported in a frozen state to the cold-room facilities of the LGGE in Grenoble, France. Sample preparation for chemical measurements was carried out under clean-room laboratory conditions. After stratigraphic observations and measurements of bulk density, the firn core was divided in two half cores. One half was dedicated to radioactivity measurements and the other half was analysed using ion chromatography and mass spectrometry (Sect. 2.2). Subannual resolution sampling and gross beta radioactivity and gamma spectrometry for bomb test markers allowed us to build the S1C1 firn core chronology (Sect. 2.3).

\subsection{Measurements}

Discrete density values were calculated based on snow sample volume and mass measurements with a $50 \mathrm{~cm}$ resolution, from the surface to $22.4 \mathrm{~m}$ depth. The resulting values range from 400 to $700 \mathrm{~kg} \mathrm{~m}^{-3}$ (Table S2 in the Supplement). Accounting for measurement difficulties due to 
weak cohesion of snow in the first few metres, and considering measurement errors, the associated uncertainties are $\pm 20-25 \mathrm{~kg} \mathrm{~m}^{-3}$ ( $\pm 4 \%$ ) from the surface to $7 \mathrm{~m}$ depth, and $\pm 15 \mathrm{~kg} \mathrm{~m}^{-3}$ ( $\pm 2 \%$ ) from 7 to $22.4 \mathrm{~m}$. Hereafter, density values are used to convert snow depths into water equivalent depths.

Firn core sections were processed for artificial radioactivity measurements by low-level (i) beta counting and (ii) gamma spectrometry, with a continuous sampling every $50 \mathrm{~cm}$ from the surface to $22.4 \mathrm{~m}$ depth. Using a method developed by Delmas and Pourchet (1977) and improved by Magand (2009), snow samples (100-200 g) were melted, weighed, acidified and filtered on ion exchange paper, on which radionuclides of interest $\left({ }^{90} \mathrm{Sr},{ }^{137} \mathrm{Cs},{ }^{241} \mathrm{Am}\right.$ - daughter of ${ }^{241} \mathrm{Pu}$ ) were trapped. All steps were realised in the LGGE clean room laboratory to prevent any contamination. After drying (in an oven at $60^{\circ} \mathrm{C}$ ), these filters were first analysed by a beta gas-proportional counting system (gross beta measurement) to determine the presence of beta emitters peaks corresponding to the global fallout of nuclear weapons of the 1950s and the 1960s. In a second step, very low-level gamma spectrometry (coaxial germanium detector) measurements were taken on the filters to determine activities of ${ }^{137} \mathrm{Cs}$ and ${ }^{241} \mathrm{Am}$. Both $1955 \pm 1 \mathrm{AD}$ and $1965 \pm 1 \mathrm{AD}$ peaks were clearly identified in the S1C1 core, respectively at 19.5$20.0 \mathrm{~m}$ and $16.5-17.0 \mathrm{~m}$ depth (red vertical lines, Fig. 2).

Along the $\mathrm{S} 1 \mathrm{C} 1$ core, each $5 \mathrm{~cm}$ sample was analysed for ionic concentrations and the oxygen isotopic ratio. The firn pieces dedicated to the ion analysis were decontaminated under a clean air bench located in a cold room $\left(-15^{\circ} \mathrm{C}\right)$ using a pre-cleaned electric plane tool onto which the ice is slid (Preunkert and Legrand, 2013). A total of 427 subsamples were obtained along the $22.4 \mathrm{~m} \mathrm{S1C}$ core, with a $5 \mathrm{~cm}$ sample resolution. Concentrations of cations $\left(\mathrm{Na}^{+}\right.$and $\left.\mathrm{NH}_{4}^{+}\right)$and anions $\left(\mathrm{Cl}^{-}, \mathrm{NO}_{3}^{-}, \mathrm{SO}_{4}^{2-}\right.$ and methanesulfonate; hereafter MSA), were analysed by ion chromatography (IC) equipped with a CS12 and an AS11 separator column, respectively. Finally, the oxygen isotopic ratio analysis was processed using the $\mathrm{CO}_{2} / \mathrm{H}_{2} \mathrm{O}$ equilibration method on a Finnigan MAT252 using two different internal water standards calibrated to SMOW/SLAP (Standard Mean Ocean Water/ Standard Light Antarctic Precipitation) international scales. The accuracy of each measurement is $\pm 0.05 \%$ o $(1 \sigma)$ (Table S1 in the Supplement).

\subsection{Methodology for layer counting}

As shown by Jourdain and Legrand (2002), all ions exhibit a summer maximum at DDU, as also found for different Antarctic coastal stations for nitrate (Wagenbach et al., 1998b), ammonium (Legrand et al., 1998), MSA and sulfate (Minikin et al., 1998). The sodium seasonal pattern at DDU (maximum in summer) is reversed compared to those observed at other coastal Antarctic sites (e.g. Halley and
Neumayer), a feature already discussed by Wagenbach et al. (1998a).

The outstanding summer maximum of sea-salt concentrations only detected at DDU is related to its location on a small island, immediately surrounded by open ocean from December to February. With the aim of using the seasonality of sulfate and MSA produced by oxidation of dimethyl sulfur emitted in summer by marine phytoplankton, we have calculated the non-sea-salt sulfate concentrations in the $\mathrm{S} 1 \mathrm{C} 1$ core. Wagenbach et al. (1998a) showed that at the coastal Antarctic sites, sea-salt aerosol exhibits a strong depletion of atmospheric sulfate in winter due to precipitation of mirabilite $\left(\mathrm{Na}_{2} \mathrm{SO}_{4} \cdot 10 \mathrm{H}_{2} \mathrm{O}\right)$ on the sea-ice surface (Wagenbach et al., 1998a). In order to quantify non-sea-salt (nss) $\mathrm{SO}_{4}^{2-}$ contribution, different sulfate to sodium ratio should be defined for summer $(0.25$, i.e. the reference seawater value) and winter ( 0.13 derived by Jourdain and Legrand, 2002 for DDU):

$$
\begin{aligned}
{\left[\mathrm{nssSO}_{4}^{2-}\right]_{\text {summer }} } & =\left[\mathrm{SO}_{4}^{2-}\right]-0.25\left[\mathrm{Na}^{+}\right] \\
{\left[\mathrm{nssSO}_{4}^{2-}\right]_{\text {winter }} } & =\left[\mathrm{SO}_{4}^{2-}\right]-0.13\left[\mathrm{Na}^{+}\right] .
\end{aligned}
$$

Note that the volcanic horizons related to the eruptions of Mt Agung (1963) and Pinatubo (1991) are not detected in the $\mathrm{nsSSO}_{4}^{2-}$ profile. Legrand and Wagenbach (1999) explained this feature by the fact that, in coastal Antarctica, the volcanic perturbation remained weak with respect to the year-to-year variability of marine biogenic sulfate. While the relationship between concentrations in snow and in simultaneously sampled air remains poor for all compounds (Wolff et al., 1998), there is a general seasonal coincidence of the maxima. Annual layer counting is therefore based on our assessment of the concurrence of synchronous maximum values for $\mathrm{Na}^{+}, \mathrm{MSA}, \mathrm{SO}_{4}^{2-}, \mathrm{NH}_{4}^{+}, \mathrm{NO}_{3}^{-}$and $\delta^{18} \mathrm{O}$, which is used to objectively identify summer horizons. The combination of information on annual layer counting as well as absolute age markers used to build the $\mathrm{S1C} 1$ age scale is described in Sect. 3.1 (Results).

\subsection{Regional climate records}

We extracted DDU monthly near-surface air temperature data spanning the period 1958-2006 from the Reference Antarctic Data for Environmental Research (READER) dataset (https://legacy.bas.ac.uk/met/READER/) (Turner et al., 2004). We also calculated annual mean values of wind speed spanning the period 1950-2006 (with gaps in years 1953-1955) at DDU (P. Pettré, personal communication, 2016). Finally, we extracted the average sea-ice concentration from the Nimbus-7 Scanning Multichannel Microwave Radiometer (SMMR) and Defense Meteorological Satellite Program Special Sensor Microwave/Imagers - Special Sensor Microwave Image/Sounder (DMSP SSM/I-SSMIS) passive microwave data (http://nsidc.org/data/nsidc-0051) and focused on the region situated between 90 and $150^{\circ} \mathrm{E}$ (Center, 1996). We used these datasets to perform linear regression analysis with the $\mathrm{S} 1 \mathrm{C} 1 \delta^{18} \mathrm{O}$ and accumulation records. 


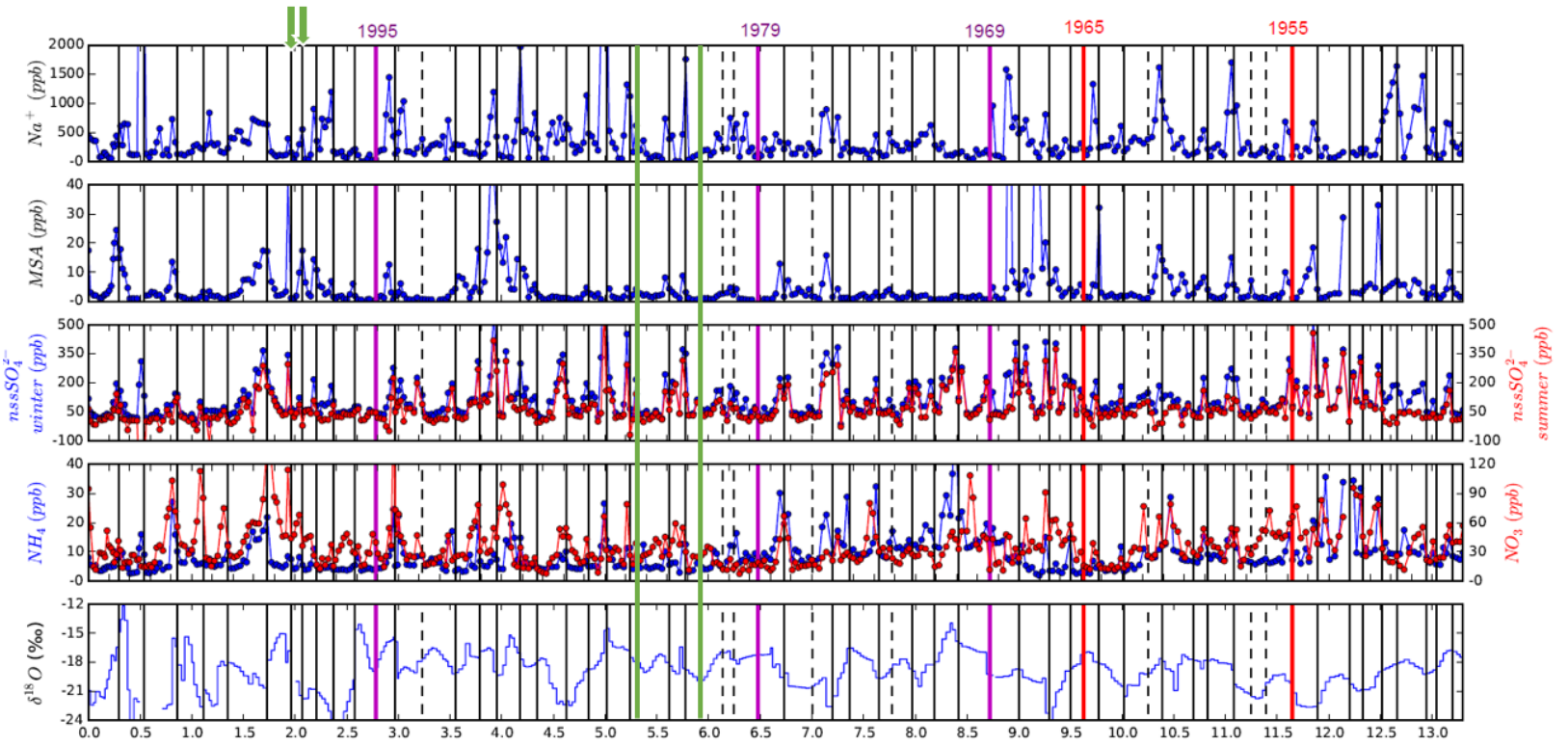

Figure 2. Dating of the $\mathrm{S} 1 \mathrm{C} 1$ core based on sodium $\mathrm{Na}^{+}$, methanesulfonic acid (MSA), non-sea-salt sulfate (nssSO ${ }_{4}^{2-}$ ), ammonium $\mathrm{NH}_{4}^{+}$, nitrate $\left(\mathrm{NO}_{3}\right)$ and $\delta^{18} \mathrm{O}$. The black lines correspond to the December-January period of each year (solid lines are the layers for which all sources of information are consistent, while dashed lines are the layers for which we have contrasted results from one or more sources of information), the purple lines to the non-full retreat horizons and the red lines to the nuclear test horizons. $\delta^{18} \mathrm{O}$ data are shown as horizontal steps because one measurement corresponds to a value averaged over a $5 \mathrm{~cm}$ sample. Green lines stress the years which were added for the second dating, while the green arrows stress those which were deleted (see text for details).

\subsection{Atmospheric simulations}

In this paper, we refer to two simulations, one by the AGCM ECHAM5-wiso and one by the regional atmospheric model MAR.

ECHAM5 (Roeckner et al., 2003) has been equipped with stable water isotopes (Werner et al., 2011). This model, named ECHAM5-wiso, leads to realistic simulations when evaluated against observations of isotopic composition in precipitation and water vapour on a global scale. More specifically, the simulated distribution of annual mean precipitation isotopic composition over Antarctica is in good agreement with the spatial isotopic dataset compiled from snow and ice-core data (Masson-Delmotte et al., 2008).

In addition to the most common stable water isotope $\mathrm{H}_{2}{ }^{16} \mathrm{O}, \mathrm{H}_{2}{ }^{18} \mathrm{O}$ and HDO were implemented into the hydrological cycle of ECHAM5-wiso, in a more analogous manner than in the previous model releases of ECHAM3 (Hoffmann et al., 1998) and ECHAM4 (Werner et al., 2001). Each water phase (vapour, cloud liquid and cloud ice) being transported independently in ECHAM5-wiso contains its isotopic counterpart, implemented in the model code. Equilibrium and kinetic fractionation processes are taken into account during any phase change of a water mass.

The ECHAM5-wiso model simulation analysed in this study covers the period 1960-2006. ECHAM5-wiso was nudged to atmospheric reanalyses from ERA40 (Uppala et al., 2005) and ERA-Interim (Dee et al., 2011), which was shown to have good skills for Antarctic precipitation (Wang et al., 2016), surface pressure fields as well as vertical profiles of winds and temperature. The ocean-surface boundary conditions (sea ice included) are prescribed based on ERA40 and ERA-Interim data. Isotopic values of ocean surface waters are based on a compilation of observational data (Schmidt et al., 2007). The simulation was performed at a T106 resolution (which corresponds to a mean horizontal grid resolution of approx. $1.1^{\circ} \times 1.1^{\circ}$ ). We used the model results at the grid point closest to our site of interest.

The MAR (Modèle Atmosphérique Régional) model is a limited-area coupled atmosphere-blowing snow-snow pack model. Atmospheric dynamics are based on the hydrostatic approximation of the primitive equations (Gallée and Schayes, 1994). The vertical coordinate is the normalised pressure. The parameterisation of turbulence in the surface boundary layer (SBL) takes into account the stabilisation effect by the blowing snow flux, as in Gallée et al. (2001). Turbulence above the SBL is parameterised using the local E $\varepsilon$ model by Bintanja (2000). Prognostic equations are used to describe five water species (Gallée, 1995): specific humidity, cloud droplets and ice crystals, rain drops and snow particles. A sixth equation is added, describing the number of ice crystals. Cloud microphysical parameterisations are based on the studies of Kessler (1969), Lin et al. (1983), Meyers et al. (1992) and Levkov et al. (1992). The radiative transfer through the atmosphere is parameterised as in Mor- 
crette (2002). Surface processes in MAR are modelled using the Soil Ice Snow Vegetation Atmosphere Transfer (SISVAT) scheme (Gallée et al., 2001). In particular, the snow surface albedo depends on the snow properties (dendricity, sphericity and size of the snow grains). Finally the blowing snow model is described in Gallée et al. (2013). MAR is set up over Antarctica with a horizontal resolution of $40 \mathrm{~km}$ over $200 \times 200$ grid points. Lateral forcing and sea-surface conditions (SST and sea-ice fraction) are taken from ERA-Interim (Dee et al., 2011). There are 33 levels in the vertical with a high vertical resolution in the lower troposphere. The first level is situated at $3 \mathrm{ma}$ a.g.l. The simulation was performed from 1 January 1990 to 31 December 2010.

Hereafter, we use the ECHAM5-wiso simulation to explore the suitability of local precipitation $\delta^{18} \mathrm{O}$ to identify seasonal cycles, as no regional precipitation monitoring data are available. We then compare the ECHAM5-wiso $\left(\delta^{18} \mathrm{O}\right.$, temperature and accumulation) and MAR (temperature and accumulation) outputs with our ice-core records.

\section{Results}

\subsection{Age scale}

\subsubsection{Information from ECHAM5-wiso on annual $\delta^{18} \mathrm{O}$ cycles}

In order to assess whether annual layer counting was possible using a $\delta^{18} \mathrm{O}$ seasonal cycle, we investigate seasonal patterns in ECHAM5-wiso outputs and the timing of the maximum precipitation $\delta^{18} \mathrm{O}$ value for each year. The mean simulated precipitation $\delta^{18} \mathrm{O}$ seasonal cycle over the period 1979-2006 (28 years) shows a maximum in December-January, a minimum in May and an overall amplitude of $4.5 \%$. The timing of the simulated monthly precipitation $\delta^{18} \mathrm{O}$ maximum fluctuates from year to year. Out of the 29 years, it was simulated at $80 \%$ during local spring-summer: seven times in December (i.e. $24 \%$ ), eight times in November (i.e. $28 \%$ ) and eight times in January (i.e. $28 \%$ of the time). However, several occurrences were simulated in autumn: three times in March (i.e. 10\%), once in February (i.e. $3 \%$ ), and in winter, two times in August (i.e. $7 \%$ ) (Table S3). From this analysis, assuming that the ECHAM5-wiso model is a perfect representation of reality, peak $\delta^{18} \mathrm{O}$ has a $80 \%$ likelihood of occurring in December \pm 1 month. If a chronology was purely based on $\delta^{18} \mathrm{O}$, the occurrence of maxima during other seasons may therefore lead to age-scale errors of up to 6 months.

\subsubsection{Absolute age horizons}

Following major nuclear tests in the atmosphere, radioactive debris was injected into the stratosphere in 1953-1954 and 1963-1964 and reported to be deposited in Antarctica in 1955 and 1965 ( \pm 1 year) (Picciotto and Wilgain, 1963). These two dates are indicated by red vertical lines in Fig. 2.
Table 1. Occurrence of species not showing a summer peak for an identified summer (data missing in summer, peaks not identified at all or two or three peaks appearing for the same year).

\begin{tabular}{lrrr}
\hline & $\begin{array}{r}\text { Data missing } \\
\text { in summer }\end{array}$ & $\begin{array}{r}\text { Peaks not } \\
\text { identified }\end{array}$ & $\begin{array}{r}\text { two or } \\
\text { three peaks }\end{array}$ \\
\hline $\mathrm{Na}^{+}$ & 0 & 4 & 9 \\
$\mathrm{MSA}$ & 4 & 10 & 2 \\
$\mathrm{nssSO}_{4}^{2-\text { summer }}$ & 0 & 4 & 5 \\
$\mathrm{nssSO}_{4}^{2-}$ winter & 0 & 0 & 6 \\
$\mathrm{NH}_{4}^{+}$ & 0 & 7 & 5 \\
$\mathrm{NO}_{3}^{-}$ & 0 & 1 & 7 \\
$\delta^{18}$ & 2 & 25 & 0 \\
\hline
\end{tabular}

Aerosol monitoring data from DDU (1991-2015) show an unequivocal fingerprint of rare summers during which the sea-ice retreat was not complete offshore the site through the absence of sodium maximum. Such events were observed in January 1995 (Jourdain and Legrand, 2002), and more recently in January 2012 and 2013 (Legrand et al., 2016). Prior to the start of DDU atmospheric monitoring in 1991 and to the availability of satellite sea-ice data in January 1979, two other years were characterised by a non-complete seaice retreat in summer offshore DDU, namely January 1969 and January 1979 (Patrice Godon, personal communication, 2016). The identification of years 1995, 1969 and 1979 in S1C1 records is indicated by purple vertical lines in Fig. 2. Note that the chemical fingerprint of summer 1969 is equivocal, as it is defined by the absence of a sodium maximum, but coincides with a sulfate maximum, contrary to what is expected.

\subsubsection{Combining layer counting with absolute age horizons}

We assessed the concurrence of synchronous maximum values for $\mathrm{Na}^{+}, \mathrm{MSA}, \mathrm{SO}_{4}^{2-}, \mathrm{NH}_{4}^{+}, \mathrm{NO}_{3}^{-}$and $\delta^{18} \mathrm{O}$ to objectively identify summer horizons, indicated by the vertical continuous black lines in Fig. 2. Only four layers showed simultaneous peaks in all species (in 1959, 1966, 1984 and 2001). In the other cases, the determination was equivocal: either data were missing for the depth interval corresponding potentially to summer or peaks were not identified; conversely two or three peaks appeared. Table 1 reports the number of occurrence of such cases for each species. We note that maxima in $\mathrm{NO}_{3}^{-}$and $\delta^{18} \mathrm{O}$ were often delayed with respect to maxima in other species. These two parameters can potentially be affected by diffusion in the firn, due to snowvapour interactions (Johnsen, 1977; Mulvaney et al., 1998). Mulvaney et al. (1998) also reported that MSA could migrate into the firn. Potential seasonal signals had a very low amplitude (e.g. 1969 to 1975), and sometimes no signal could be discerned. Altogether, $\mathrm{nsSSO}_{4}^{2-}$ winter seems to be the most 


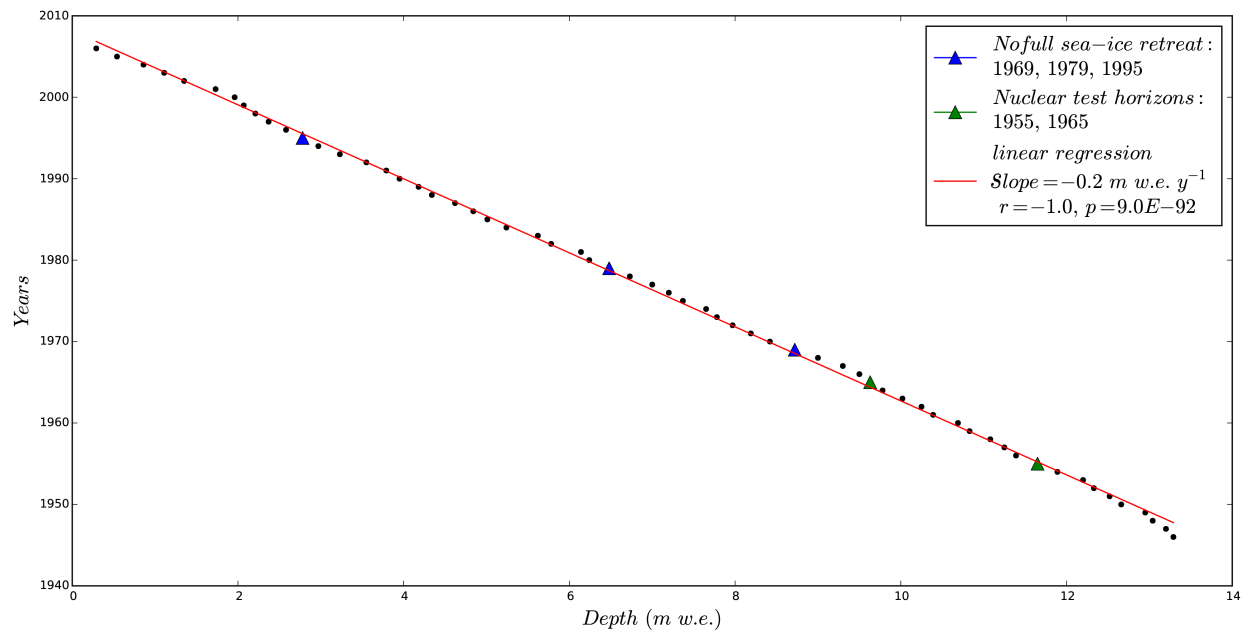

Figure 3. Depth-age relationship based on the dating of the S1C1 core.

reliable species for identifying seasonal cycles in the $\mathrm{S1C} 1$ core, as a seasonal pattern appears for every layer.

The remaining difficulty is associated with multiple peaks within 1 year. This appears, for instance, in the year 1993 (represented in dashed vertical line in Fig. 2). Double peaks may be associated with 1993 only or with 2 successive years. Such situations were encountered eight times (dashed vertical lines in Fig. 2). As a result, we made subjective choices for the identification of annual or subannual peaks in order to optimise the coherency with absolute age markers.

We found 60 summer peaks (solid lines, Fig. 2), whereas the initial layers excluded from the final chronology are represented with dashed lines. As a result, the S1C1 ice core spans the period 1946-2006, as displayed in a depth-age (depth expressed in metre water equivalent) scale (Fig. 3).

\subsection{Record of accumulation variability and comparison with stake measurements}

Annual accumulation variations were extracted from the S1C1 core by combining density measurements with annual mean layer counting (Fig. 4). The resulting annual accumulation varies between 9.4 and $38.0 \mathrm{~cm}$ w.e. $\mathrm{yr}^{-1}$, with a mean value of $21.8 \mathrm{~cm}$ w.e. $\mathrm{yr}^{-1}$ and a standard deviation of $6.9 \mathrm{~cm}$ w.e. $\mathrm{yr}^{-1}$. This value is $15 \%$ lower than the annual accumulation of $25.6 \mathrm{~cm}$ w.e. $\mathrm{yr}^{-1}$ (standard deviation of $15.1 \mathrm{~cm}$ w.e. $\mathrm{yr}^{-1}$ ) measured between 2004 and 2015 on one stake located closest to the drilling site (Agosta et al., 2012) (Fig. 1b) or $27 \%$ lower than the mean value measured nearly at the same location between 1971 and 1991 (mean value of $29.9 \mathrm{~cm}$ w.e. $\mathrm{yr}^{-1}$ and standard deviation of $26.6 \mathrm{~cm}$ w.e. $\mathrm{yr}^{-1}$ ). We identified remarkable years as those for which accumulation deviates from the mean value by more than 2 standard deviations. Remarkably high accumulation rates were encountered in 1981, 1983 and in 2001 (at respectively $35.9,37.3$ and $38.0 \mathrm{~cm}$ w.e. $\mathrm{yr}^{-1}$ ). No remark- ably low accumulation rates were found. These remarkable years can be found neither in the stake average record nor in the stake data closest to the $\mathrm{S} 1 \mathrm{C} 1$ site. For stake accumulation measurements taken at the stake closest to $\mathrm{S} 1 \mathrm{C} 1$, the highest values were measured in 1979 and 1981 (75.8 and $73.8 \mathrm{~cm}$ w.e. $\mathrm{yr}^{-1}$ ). Moreover, small and non-significant linear correlation coefficients are found with the stake average record, and with the stake data the closest to the $\mathrm{S1C} 1$ site. Spectral analyses performed using the multi-taper method (Paillard et al., 1996) reveal significant periodicities of 6 and 8 years (harmonic $F$ test $\geq 0.94$ ). We also note a periodicity of 12 years, which is not detected as significant (harmonic $F$ test $=0.8$ ). Decadal variability is characteristic of the high latitudes of the Southern Hemisphere (Yuan and Yonekura, 2011). This motivates filtering using a 13-point binomial filter with bounce end effects (Fig. 5), i.e. repeating the first (last) value six times in order to calculate the six first (last) running means. From this analysis, we observe a slight accumulation increase from the 1950 s to the 1980 s, with secondary maxima in the 1970s and 1990s (Fig. 5). A decrease appears from the 1980s to the 2000s, back to the initial mean level. Finally, the S1C1 core displays an unprecedented accumulation increase from the 1990s to the 2000s. This latter feature is surprising, as recent stake measurements from this area show no increase in mean values in 2004-2015 compared with earlier surveys (1971-1991). We therefore remain cautious about the recent accumulation increase inferred from one single ice-core record, unless this finding can be supported by other lines of evidence. Finally, note that only a 5-year periodicity emerges from spectral analysis of DDU temperature (harmonic $F$ test $=0.99$ ).

\subsection{Record of $\delta^{18} \mathrm{O}$}

With our age scale, each year is documented with 2 to 14 $\delta^{18} \mathrm{O} 5 \mathrm{~cm}$ measurements, with a mean number of 7 values 

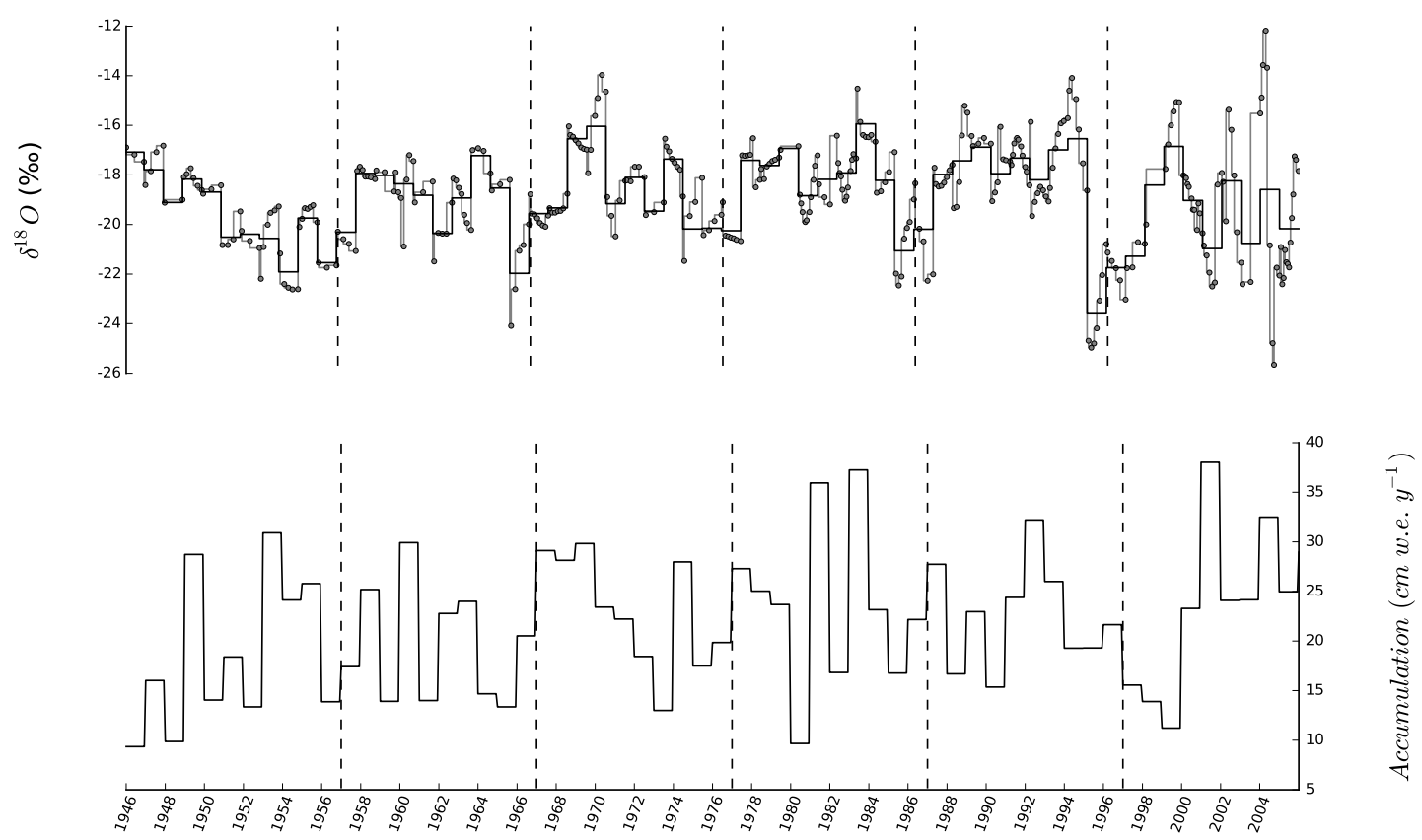

Figure 4. Time series of $\delta^{18} \mathrm{O}$ (in \%o) and accumulation (in $\mathrm{cm}$ w.e. $\mathrm{yr}^{-1}$ ) extracted from the $\mathrm{S} 1 \mathrm{C} 1 \mathrm{core}$. In the first plot, grey points correspond to the raw data, while the stepped line corresponds to the annual mean of the resampled data (with seven steps).

per year. Hereafter, the $\delta^{18} \mathrm{O}$ record is resampled at this average temporal resolution using the Fourier method (Fig. 4). Annual mean $\delta^{18} \mathrm{O}$ values are then calculated from January to December, for comparison with accumulation and other observational or simulation datasets (Fig. 5).

\subsubsection{Other sources of information for $\delta^{18} \mathrm{O}$ regional variability}

Very few multi-year direct records of snowfall isotopic composition are available from Antarctica (Fujita and Abe, 2006; Landais et al., 2012; Schlosser et al., 2016), and none in our region of interest. Near S1C1, the single direct observation arises from a collection of 19 samples of precipitation at DDU, spanning the period from February to November of 1977 (J. Jouzel, personal communication, 2016). These data depict a mean $\delta^{18} \mathrm{O}$ value of $-18.0 \%$, a standard deviation of $3.9 \%$, with the lowest value in August $(\sim-27.7 \%$ o) and the highest values in March $(-10.0 \%$ ) and November $(-11.5 \%)$. Despite its brevity, this dataset shows less depleted values, a different seasonal pattern (i.e. maxima do not appear at the same months), and lower variability than at Dome $\mathrm{C}$, where recent measurements are available for the period 2008-2010 (Stenni et al., 2016). At Dome C, precipitation isotopic composition values range from -80.6 to $-35.5 \%$, with a mean $\delta^{18} \mathrm{O}$ value of $-58.0 \%$, a standard deviation of $8.6 \%$ and a $\sim 37 \%$ mean seasonal amplitude, with maximum values in December-January, as for near-surface air temperature. This comparison is of course limited by the short dataset available for DDU and the fact that these measurements were not taken over the same time period. The distribution of $\delta^{18} \mathrm{O}$ data at DDU appears to be consistent with the range of values observed in a multidecadal (1982-1996) record of surface snow isotopic composition obtained from the coastal station of Neumayer, with a mean $\delta^{18} \mathrm{O}$ value of $-20.6 \%$ and a seasonal amplitude varying from 14.6 to $29.0 \%$ (Schlosser et al., 2008). Finally, the Dumont d'Urville precipitation mean $\delta^{18} \mathrm{O}$ value is also quite close to that of shallow ice cores from Law Dome $\left(66.73^{\circ} \mathrm{S}, 112.83^{\circ} \mathrm{E}, 1395 \mathrm{~m}\right.$ a.s.l.) (Delmotte et al., 2000; Masson-Delmotte et al., 2003), which display a mean value of $\sim-21 \%$, and an average seasonal $\delta^{18} \mathrm{O}$ amplitude of $\sim 6 \%$, together with a larger interannual variability in local winter than in local summer.

\subsubsection{Record of $\delta^{18} \mathrm{O}$ variability and links with accumulation and regional climate records}

The subannual record from raw measurements and resampling at an average of 7 points per year displays large year-toyear variations in the amplitude of the seasonal cycle, varying from $0.2 \%$ (in 1980) to $13.5 \%$ (in 2005), with a mean value of $2.5 \%$. The $\mathrm{S} 1 \mathrm{C} 1$ record clearly displays a smaller intraannual range than observed in DDU precipitation $(17.7 \%$ o for one single year), and an average intra-annual range about twice smaller than shallow ice-core records from Law Dome (typically $5 \%$ o). Note that the annual accumulation rate at Law Dome $\left(64 \mathrm{~cm}\right.$ w.e. $\left.\mathrm{yr}^{-1}\right)$ is $\sim 3$ times higher than in the $\mathrm{S} 1 \mathrm{C} 1$ core $\left(21.9 \mathrm{~cm}\right.$ w.e. $\left.\mathrm{yr}^{-1}\right)$. However, the confidence in this finding is limited by the resolution of our record as well 

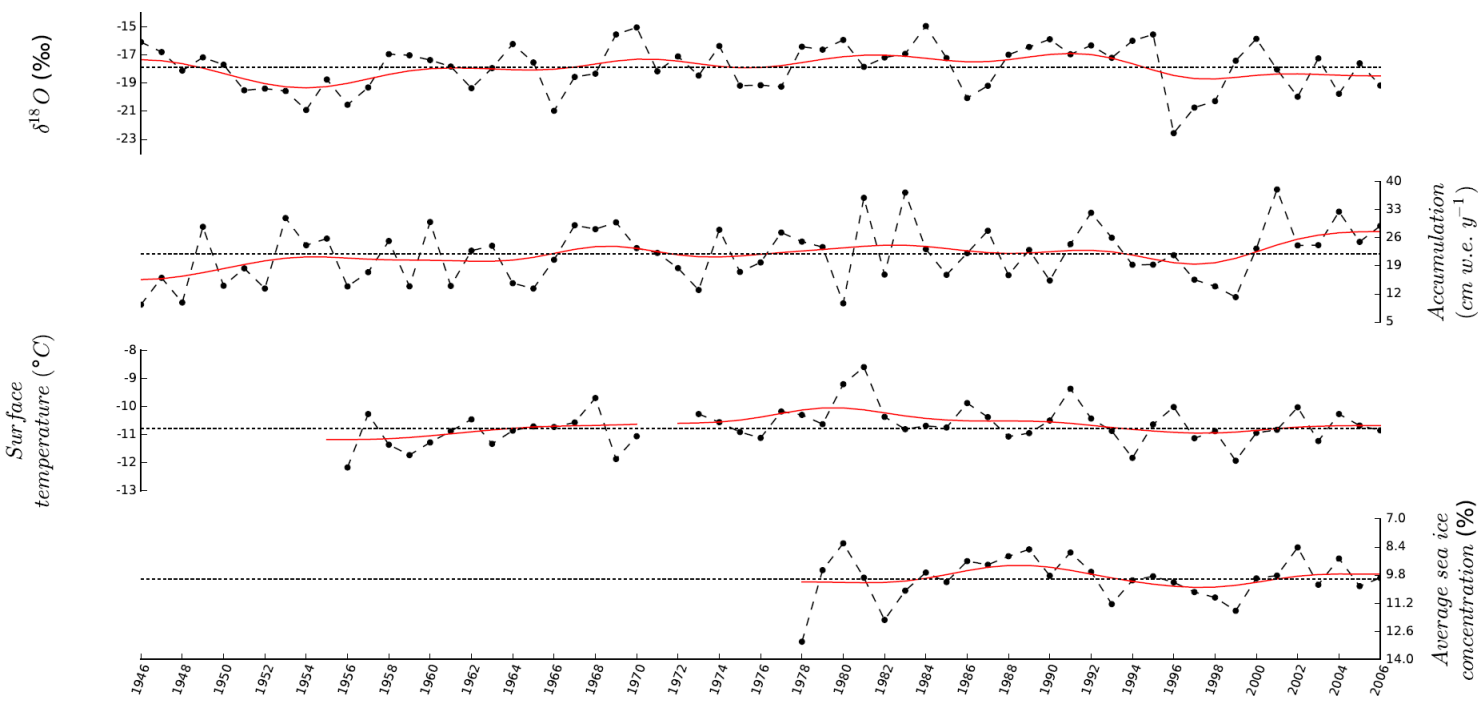

Figure 5. Comparison of the (resampled) $\delta^{18} \mathrm{O}(\%)$ and the annual accumulation (cm w.e. $\mathrm{yr}^{-1}$ ) from the S1C1 core, with the near-surface temperature (in ${ }^{\circ} \mathrm{C}$ ) extracted from the READER data base for Dumont d'Urville station (https://legacy.bas.ac.uk/met/READER/) and the Average sea-ice concentration extracted between 90 and $150^{\circ} \mathrm{E}$ from the Nimbus-7 SMMR and DMSP SSM/I-SSMIS passive microwave data (http://nsidc.org/data/nsidc-0051). Note that the $y$ axis of the lowest panel is reversed, to ensure visual coherency between lower sea-ice extent and higher temperatures. Black points linked by a dotted line correspond to the annual time series while the red lines correspond to the 13-point binomial filters with bounce end effects.

as by potential post-deposition processes affecting the preservation of the subseasonal to seasonal precipitation isotopic composition signal (Johnsen, 1977; Touzeau et al., 2016).

We again identified remarkable years as those deviating from the mean value by more than 2 standard deviations. Only one remarkably low $\delta^{18} \mathrm{O}$ values was encountered in 1996, while no remarkably high $\delta^{18} \mathrm{O}$ values was encountered. The year 1984 is marked by the most enriched annual mean $\delta^{18} \mathrm{O}$ values of the whole series. No long-term trend is observed. Spectral analyses performed using the multitaper method evidence highly significant periodicities of 6 and 14 years (harmonic $F$ test $>0.99$ ), close to those identified for accumulation. This former result leads us to use a 13-point binomial filter with bounce end effects, allowing us to explore the $\mathrm{S} 1 \mathrm{C} 1 \delta^{18} \mathrm{O}$ record at the decadal scale and to compare it with accumulation at the same scale (Fig. 5). The resulting calculations depict a sharp decrease in the 1950s, with the strongest decadal minimum peaking in 1955 . It is followed by a gradual increase, reaching the highest $\delta^{18} \mathrm{O}$ decadal-mean values in $\sim 1982$ and $\sim 1992$, with secondary maxima in $\sim 1962$ and $\sim 1972$. A sharp decrease occurs in the 1990s, when mean levels from the 1950s are reached again. There is an anti-phase of the $\delta^{18} \mathrm{O}$ and accumulationsmoothed signals in the 1950 s and the 2000s, while they appear in phase from the 1970 s to 1990 s, with multi-decadal variations.

We now explore linear relationships between the S1C1 records and regional climate records (Table 3). No significant linear correlation is identified between annual mean S1C1 $\delta^{18} \mathrm{O}$ and accumulation records from 1946 to 2006 . We also note that there is no coincidence between remarkable years for $\delta^{18} \mathrm{O}$ and for accumulation.

There is no significant correlation between annual mean S1C1 $\delta^{18} \mathrm{O}$ and DDU near-surface air temperature over the available period at the annual scale. At the decadal scale, we observe a significant positive correlation, with a slope of $1.49 \% 0^{\circ} \mathrm{C}^{-1}$. Linear relationships between $\delta^{18} \mathrm{O}$ and nearsurface air temperature were found in other Antarctic stations. At Law Dome, the DE08 ice Australian $\delta^{18} \mathrm{O}$ record displays a weak negative correlation with Casey near-surface air temperature with a slope of $-0.31 \%{ }^{\circ} \mathrm{C}^{-1}(r=-0.45$ and $p=9.0 \times 10^{-3}$ for the period 1959-1991) (MassonDelmotte et al., 2003). At Dome C, over 3 years, daily precipitation $\delta^{18} \mathrm{O}$ displays a significant positive correlation with daily AWS near-surface air temperature, with a slope of $0.49 \%{ }^{\circ} \mathrm{C}^{-1}\left(r=0.79\right.$ and $\left.p=3.2 \times 10^{109}\right)$.

No significant relations are detected between annual mean $\mathrm{S} 1 \mathrm{C} 1 \delta^{18} \mathrm{O}$ and annual mean sea-ice concentration in the Adélie land sector (Table 3).

\subsection{Model-data comparison}

\subsubsection{Comparison between the ECHAM5-wiso and the S1C1 data}

This comparison is limited by the fact that we only have one firn core record, and no estimation of the deposition noise. In the future, the latter may be estimated from signal-tonoise analyses of multiple ice-core records from the same 
Table 2. Statistical analyses: minimum (Min), maximum (Max), mean $(\mu)$ and standard deviation $(\sigma)$ of the precipitation (extracted from ECHAM5-wiso) or the accumulation (from the $\mathrm{S} 1 \mathrm{C} 1$ ice core) in $\mathrm{cm}$ w.e. $\mathrm{yr}^{-1}$, the $\delta^{18} \mathrm{O}$ (extracted from ECHAM5-wiso or from the S1C1 ice core) in \%o and the $2 \mathrm{~m}$ temperature $\left(2 \mathrm{~m}-T\right.$, extracted from ECHAM5-wiso or from the READER database) in ${ }^{\circ} \mathrm{C}$ over the different available periods (1946-2007 for the S1C1 ice core and 1956-2007 for the READER database), and over the period 1979-2007.

\begin{tabular}{|c|c|c|c|c|c|c|c|c|c|c|c|c|c|}
\hline & & \multicolumn{4}{|c|}{$\begin{array}{l}\text { Precipitation (ECHAM) } \\
\text { or accumulation (S1C1) } \\
\quad\left(\mathrm{cm} \text { w.e. } \mathrm{yr}^{-1}\right)\end{array}$} & \multicolumn{4}{|c|}{$\begin{array}{c}2 \mathrm{~m}-T \\
\left({ }^{\circ} \mathrm{C}\right)\end{array}$} & \multicolumn{4}{|c|}{$\begin{array}{c}\delta^{18} \mathrm{O} \\
(\% \circ)\end{array}$} \\
\hline & & Min & Max & $\mu$ & $\sigma$ & Min & Max & $\mu$ & $\sigma$ & Min & Max & $\mu$ & $\sigma$ \\
\hline \multirow[t]{2}{*}{ S1C1 } & 1946-2006 & 9.4 & 38.0 & 21.8 & 7.0 & & & & & -23.6 & -15.9 & -18.9 & 1.7 \\
\hline & 1979-2006 & 9.7 & 38.0 & 23.1 & 7.5 & & & & & -23.6 & -15.9 & -18.7 & 1.8 \\
\hline \multirow[t]{2}{*}{ READER } & 1956-2006 & & & & & -12.2 & -8.6 & -10.7 & 1 & & & & \\
\hline & 1979-2006 & & & & & -11.9 & -8.6 & -10.6 & 0.7 & & & & \\
\hline ECHAM & 1979-2006 & 52.1 & 96.6 & 68.7 & 12.0 & -18.1 & -14.8 & -16.9 & 0.8 & -22.4 & -19.6 & -20.8 & 0.6 \\
\hline
\end{tabular}

Table 3. Linear relationship between the $\mathrm{S} 1 \mathrm{C} 1 \delta^{18} \mathrm{O}$ and regional climate records showing the coefficient correlation and the $p$ value. Note that all data from the $\mathrm{S} 1 \mathrm{C} 1$ core are annual averages from the first dating.

\begin{tabular}{lllrr}
\hline Period & Resolution & Record & $r$ & $p$ \\
\hline $1946-2006$ & annual & accumulation & $4.4 \times 10^{-3}$ & 0.97 \\
$1956-2006$ & annual & READER surface temperature & -0.13 & 0.35 \\
$1956-2006$ & decadal & READER surface temperature & 0.72 & $2.6 \times 10^{-9}$ \\
$1979-2006$ & annual & READER surface temperature & -0.15 & 0.44 \\
$1979-2006$ & annual & sea-ice concentration in Adélie Land & 0.04 & 0.82 \\
$1950-2006$ & annual & wind speed & -0.27 & 0.0666 \\
$1979-2001$ & annual & wind speed & -0.47 & 0.029 \\
\hline
\end{tabular}

area (Masson-Delmotte et al., 2015). Moreover, recent monitoring of surface snow and surface vapour isotopic composition in polar regions have suggested isotopic exchanges between surface snow and water vapour in between snowfall events (Ritter et al., 2016; Steen-Larsen et al., 2014). Such processes are not accounted for in the atmospheric models, and we can therefore only compare simulated precipitationweighted $\delta^{18} \mathrm{O}$ with our firn measurements. Similarly, we compare the ECHAM5-wiso model-simulated precipitation with the ice-core accumulation data, which may also reflect the impact of wind erosion.

The ECHAM5-wiso simulation produces a large increase in $\delta^{18} \mathrm{O}$ and precipitation after 1979 (not shown). As such an increase is not observed in the $\mathrm{S} 1 \mathrm{C} 1$ record, we suggest that it may arise from a discontinuity in the ERA reanalyses data used as boundary conditions. Indeed, the lack of sea-ice observations prior to the satellite era in the ERA-40 dataset leads to the unrealistic set of climatological sea-ice coverage values around Antarctica prior to 1979. This deficit does not exist in the ERA-Interim dataset, which starts from the year 1979. Therefore, in the following, the model-data comparison is restricted to the period 1979-2006 (Fig. 6).

The ECHAM5-wiso simulation underestimates the average seasonal amplitude of $\delta^{18} \mathrm{O}$ at the $\mathrm{S} 1 \mathrm{C} 1$ grid point by a factor of 2.0, and its interannual standard deviation by a fac- tor of 1.4. No strong similarity appears for year-to-year values. Weak but significant decreasing long-term trends appear in both the S1C1 record and in the model outputs $(r=-0.36$ and $p=0.058$ and $r=-0.43$ and $p=0.022$ respectively).

By contrast, the model precipitation amount $\left(68.4 \pm 11.7 \mathrm{~cm}\right.$ w.e. $\left.\mathrm{yr}^{-1}\right)$ is much higher than observed $\left(23.1 \pm 7.3 \mathrm{~cm}\right.$ w.e. $\left.\mathrm{yr}^{-1}\right)$ at $\mathrm{S} 1 \mathrm{C} 1$ site on the same period. This difference cannot be explained by the impact of sublimation (in average, $-4.8 \mathrm{~cm}$ w.e. $\mathrm{yr}^{-1}$ in the simulation). Note that the model may not fully account for the impact of wind erosion, due to missing parameterisations for wind scouring and misrepresentation of small-scale katabatic winds. However, snow accumulation is highly variable in this region, due to the orographic effect on precipitation and to wind scouring. Along the first $50 \mathrm{~km}$ of the stake network (Agosta et al., 2012), the mean accumulation rate is estimated at $34.6 \mathrm{~cm}$ w.e. $\mathrm{yr}^{-1}$ between 2004 and 2014. This result confirms that ECHAM5-wiso overestimates the regional accumulation rate. When considering deviations from average values (Fig. 6), no similarity emerges between interannual variations in the $\mathrm{S} 1 \mathrm{C} 1$ record and in the simulation. The simulation captures the observed positive anomalies in 1993. No significant long-term trend is identified from 1979 to 2006. 

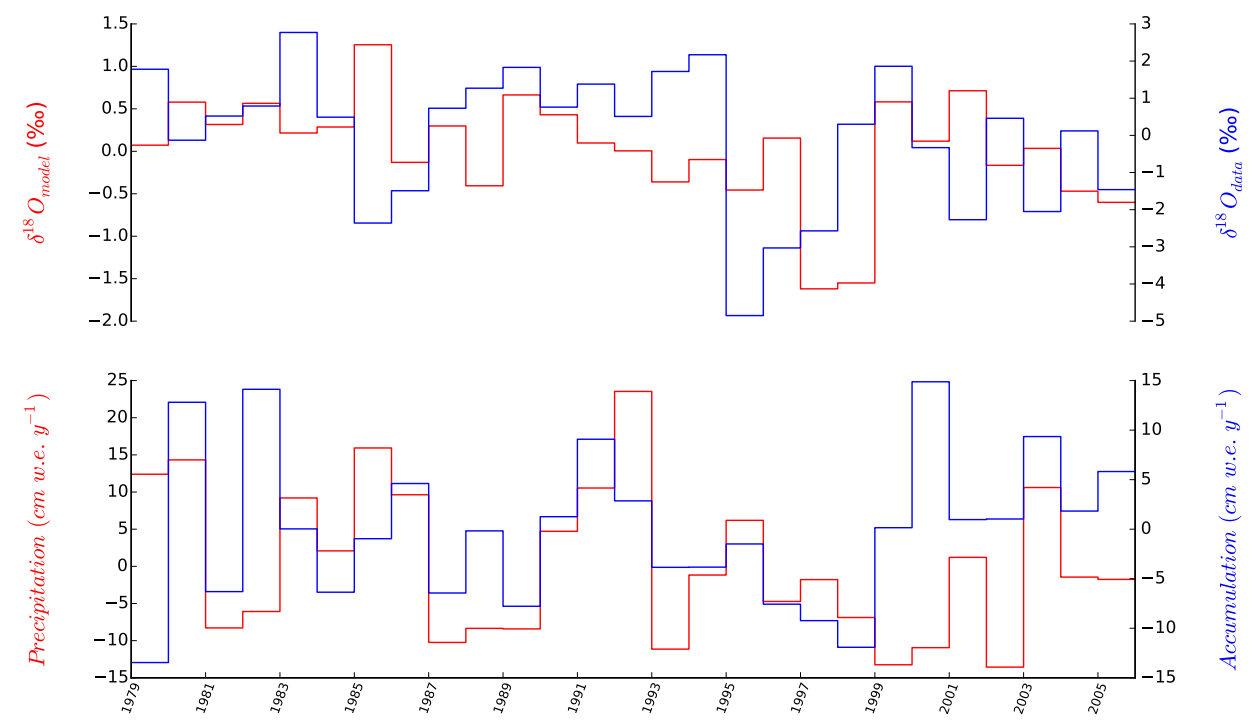

Figure 6. Model-data comparison of the anomalies (annual value minus the 1979-2006 average value) of $\delta^{18} \mathrm{O}(\%$ o) and accumulation ( $\mathrm{cm}$ w.e. $\mathrm{yr}^{-1}$ ). The blue points and dashed lines correspond to the data from the $\mathrm{S} 1 \mathrm{C} 1$ core while the red steps correspond to the simulations.

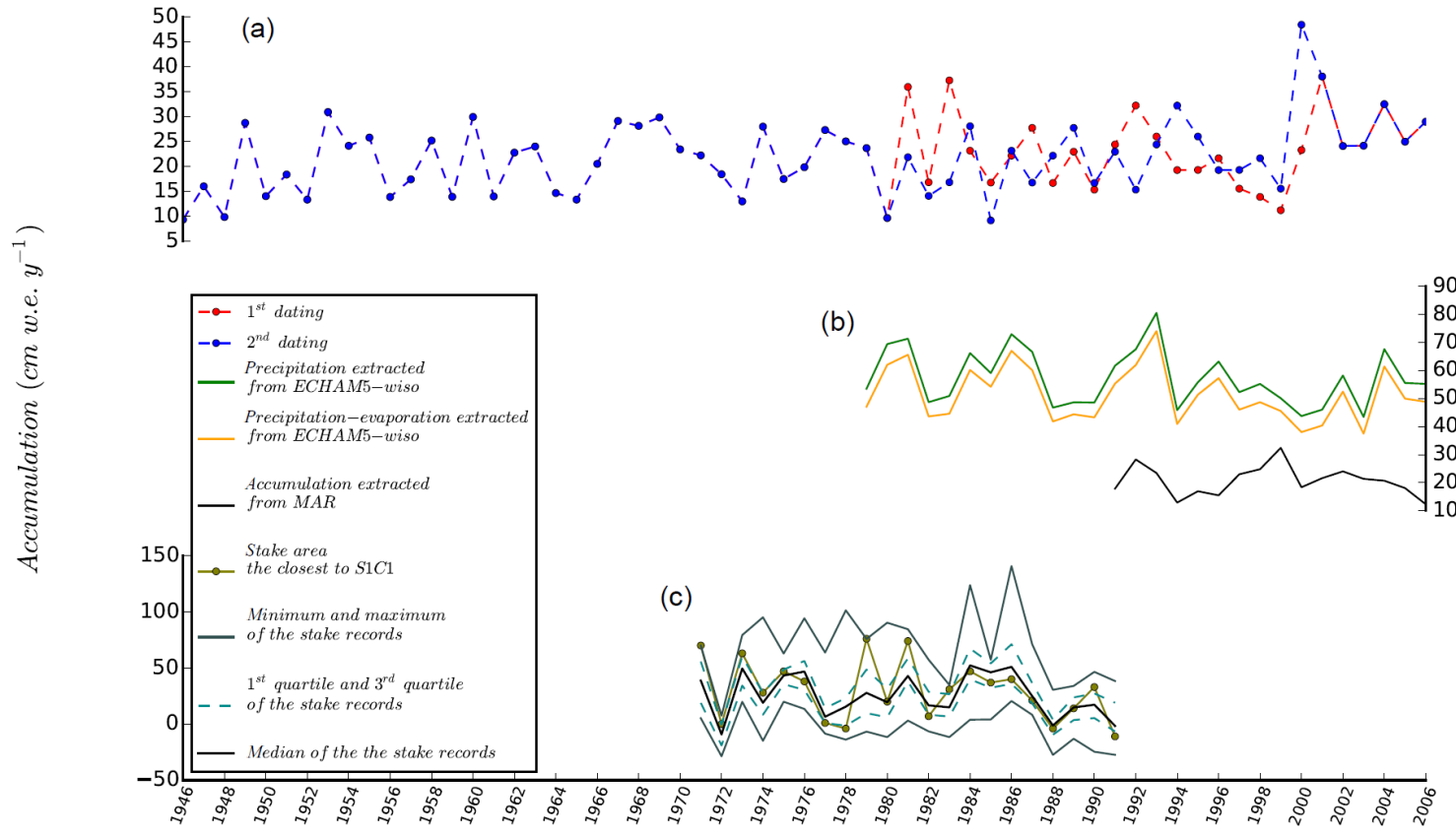

Figure 7. Comparison of accumulation data. Top panel: S1C1 reconstruction obtained from the first (red) and second (blue) dating. Note that the accumulation resulting from the first dating and second dating overlaps over 1946-1980 and 2001-2006 so only one colour line appears. Middle panel: precipitation (green) and precipitation minus evaporation (orange) simulated by ECHAM5-wiso (1979-2006), and accumulation simulated by MAR (1991-2006) (black). Lower panel: distribution of accumulation measurements from stake records, illustrated by minima and maxima (grey lines), first and third quartiles (dashed green lines), median value of stake measurements (black line) and measurements from one single stake, closest to the S1C1 site (solid green line). Two dashed vertical lines correspond to the years 1984 and 1990.

The model-data mismatch may arise from the topographic effect of the Antarctic ice sheet margin on the distribution of precipitation, and the associated isotopic distillation. The model grid size used here (approx. $1.1^{\circ} \times 1.1^{\circ}$, i.e. $110 \times$
$110 \mathrm{~km}^{2}$ ) might also be too coarse for a direct comparison of the simulation results to the $\mathrm{S} 1 \mathrm{C} 1$ drill site. Further investigations are needed, and this requires also a regional network of shallow firn core records on the Antarctic ice sheet mar- 
gin, in order to characterise spatio-temporal variations and signal-to-noise ratios.

In the simulation, we have also explored the $\delta^{18} \mathrm{O}$ precipitation and the $\delta^{18} \mathrm{O}$-temperature relationship at the annual scale. A significant linear relationship appears for temperature, with a slope of $0.29 \%{ }^{\circ} \mathrm{C}^{-1}(r=0.39$ and $p=$ 0.038). By contrast, no significant linear relationship is simulated for precipitation $(r=0.19$ and $p=0.34)$.

In summary, the ECHAM5-wiso model outputs appear to have a wet and $\delta^{18} \mathrm{O}$-depleted bias at the $\mathrm{S} 1 \mathrm{C} 1$ drill site, overestimate the interannual accumulation variability, underestimate the $\delta^{18} \mathrm{O}$ variability and its relationship with surface air temperature and fail to capture the observed $\delta^{18} \mathrm{O}-$ accumulation relationship.

Our model-data comparison is of course limited by comparing two different datasets. For the modelling results, we have analysed a pure atmospheric signal (precipitation). The signal recorded in the S1C1 core is produced by precipitation, but also potentially altered by post-deposition processes (such as sublimation, wind scouring and snow metamorphism). Also, having just one ice-core record (also associated with age-scale uncertainties) precludes an assessment of the signal-to-noise ratio. Indeed, with similar mean accumulation values, it was shown that 4-5 shallow ice cores may be needed to extract the common climatic signal in northwestern Greenland (Masson-Delmotte et al., 2015).

\subsubsection{Comparison between the ECHAM5-wiso model and the MAR model}

We now investigate the results of the regional model MAR for accumulation. MAR produces a more realistic range of accumulation, with simulated values varying from $12.3 \mathrm{~cm}$ w.e. $\mathrm{yr}^{-1}$ (in 2006) to $32.4 \mathrm{~cm}$ w.e. $\mathrm{yr}^{-1}$ (in 1999). At this $40 \mathrm{~km}$ horizontal scale (against $110 \mathrm{~km}$ in the ECHAM5wiso model), the slope of the East Antarctic ice sheet is better represented, a critical aspect for orographic precipitation. However, the interannual variability simulated by MAR is very different from that inferred from the S1C1 core compared to ECHAM5-wiso. This result may arise from the nudging technique: while the ECHAM5-wiso model is strongly nudged to reanalyses, the MAR model is only forced by large-scale circulation at the lateral boundaries and layers above $20 \mathrm{~km}$, allowing the model to build its own atmospheric circulation. We conclude that systematic caveats of the ECHAM5-wiso model for coastal Antarctic precipitation amounts may arise from its resolution.

\section{Discussion}

Here, we propose an alternative ice-core chronology, given the annual layer counting uncertainties. For that purpose, we have screened peak-to-peak relationships between S1C1 record, stake accumulation measurements and ECHAM5- wiso outputs. We first tried to optimise the match between S1C1 accumulation and stake data. However, the interannual standard deviation of S1C1 accumulation is approximately three times lower than when calculated from either individual stake records, or from the average stake record. As a result, we could not identify unequivocally remarkably low or high accumulation years as a robust signal. For instance, all stake area data show very low (close to zero) accumulation in 1972 and 1988, but no such signal can be identified in the S1C1 record. We therefore used the ECHAM5-wiso $\delta^{18} \mathrm{O}$ to test an alternative chronology (Sect. 4.1). We identified a high similarity between ECHAM5-wiso interannual precipitation variability and average stake data (Sect. 4.2). We then discussed processes that can produce non-climatic noise (Sect. 4.3). After assessing $\delta^{18} \mathrm{O}$-temperature relationships (Sect. 4.4), we finally explored the spatial relevance of climatic records from the S1C1 location (Sect. 4.5).

\subsection{An alternative age scale can improve the model-data comparison for $\delta^{18} \mathrm{O}$}

The comparison of the most remarkable annual anomalies in the $\mathrm{S} 1 \mathrm{C} 1$ and simulated $\delta^{18} \mathrm{O}$ series from ECHAM5-wiso reveals a 1-year shift: the minimum value is identified in 1996 for S1C1 but simulated in 1998, while the 1984 maximum value in the $\mathrm{S} 1 \mathrm{C} 1$ core may coincide with the simulated maximum value in 1986. Given the uncertainties of age chronology of at least 1 year and potentially several years (Sect. 3.1), we reconsidered the annual layer counting to assess whether the S1C1 chronology can be reconciled with the ECHAM5wiso $\delta^{18} \mathrm{O}$ outputs.

Indeed, the identification of the summers 1999-2000 and 2000-2001 in our initial chronology (2000 and 2001 in Fig. 2) are based on equivocal evidence due to multiple peaks in $\mathrm{NO}_{3}^{-}$and the lack of a peak in $\delta^{18} \mathrm{O}$. However, we could have missed 1 year between the initial layers associated with the summers 1981-1982 and 1982-1983, when peaks are identified in $\mathrm{Na}^{+}, \mathrm{nssSO}_{4}^{2-\text { winter }}, \mathrm{nssSO}_{4}^{2-\text { summer }}, \mathrm{NO}^{3-}$ and $\mathrm{NH}_{4}{ }^{+}$. We therefore built an alternative depth-age scale (Table S4) following these two findings (Figs. 7 and 8), and discussed the implications for the S1C1 records. Consequently, we have produced a new annual mean accumulation and $\delta^{18} \mathrm{O}$ time series from 1979 to 2006 , following the same approach (Sect. 2.3.3).

With this alternative chronology, the resulting mean accumulation does not change, and the interannual standard deviation is slightly increased $\left(21.8 \pm 7.4 \mathrm{~cm}\right.$ w.e. $\left.\mathrm{yr}^{-1}\right)$. It has no impact on $\delta^{18} \mathrm{O}$ or accumulation multi-decadal variations or trends. The resulting accumulation dataset remains nonsignificantly correlated with the stake average record and with the closest stake data. In the alternative chronology, there is still no significant $\delta^{18} \mathrm{O}$-temperature relationship between the S1C1 record and the DDU near-surface air temperature time series, and no relationship between S1C1 accumulation dataset and the ECHAM5-wiso precipitation output at 


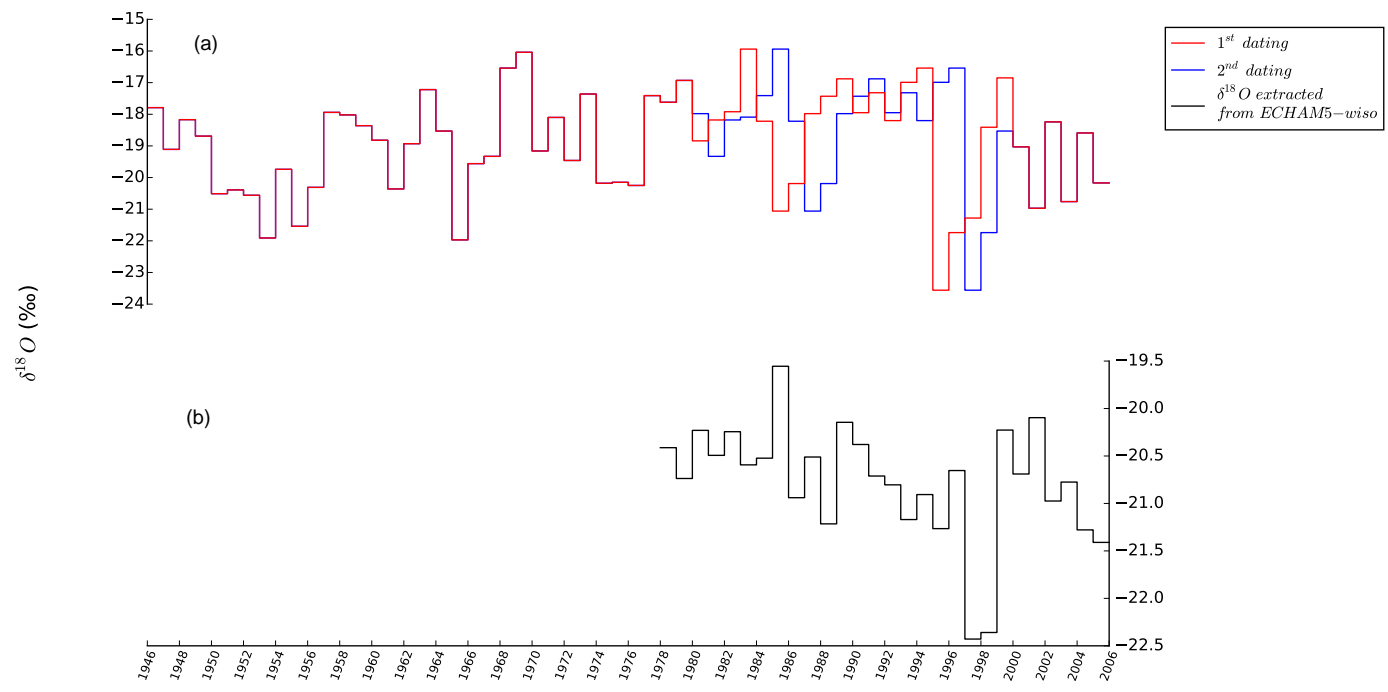

Figure 8. Comparison of $\delta^{18} \mathrm{O}$ data. Top panel: annual mean $\delta \mathrm{O}^{18}$ data from the $\mathrm{S} 1 \mathrm{C} 1$ core on the first (red) and second (blue) dating, over 1946-2006. Note that the S1C1 $\delta^{18}$ O resulting from the first dating and second dating overlap in 1946-1980 and 2001-2006, when only one colour line is displayed. Bottom: annual mean (precipitation-weighted) precipitation $\delta^{18} \mathrm{O}$ simulated by the ECHAM5-wiso model. Small vertical black lines and arrows illustrate the shift between the two S1C1 age scales for the years with the highest and lowest $\delta^{18} \mathrm{O}$ values of our record. Long vertical lines illustrate the match between the ECHAM5-wiso and S1C1 peaks used to build the second chronology.

the annual scale. However, it improves the strength of the correlation (by construction) between the $\mathrm{S} 1 \mathrm{C} 1 \delta^{18} \mathrm{O}$ and the ECHAM5-wiso $\delta^{18} \mathrm{O}$ from $r=0.17$ with $p=0.39$ for the initial chronology to $r=0.57$ with $p=1.6 \times 10^{-3}$ for the alternative chronology.

\subsection{Comparison between stake data and ECHAM5-wiso simulation}

No significant linear correlation is found between the S1C1 accumulation record (whatever chronology is used) and the stake accumulation measurements or between the S1C1 accumulation record and the ECHAM5-wiso simulated precipitation. We therefore compared the stake measurements and the ECHAM5-wiso output, with the goal of investigate whether there is a common climatic signal (for the period 1979-1991).

We observe a high and significant correlation between the ECHAM5-wiso simulated precipitation and the average stake record at the interannual scale $(r=0.62$ and $p=$ 0.030). This finding shows that the nudged ECHAM5-wiso simulation is able to capture almost $40 \%$ of the interannual average accumulation variance and that there is a clear synoptic climatic deposition (and not only local deposition) in the stake accumulation record. We also note that there is a high dispersion in the interannual variability of accumulation across the individual stake records, as evidenced by the quartile distribution (Fig. 7). Each stake record is significantly correlated with the average stake record ( $r$ varies from 0.57 to 0.90 , reaching 0.78 for the stake closest to $\left.\mathrm{S} 1 \mathrm{C} 1, p=3.2 \times 10^{-5}\right)$. However, significant differences are encountered. For instance, the sharp peak in accumulation displayed by the stake closest to S1C1 in 1979 is an outlier and is not recorded in the average stake signal. Similarly, the correlation coefficient between the ECHAM5-wiso simulated precipitation and individual stake records varies from 0.3 to 0.7 , stressing potential non-climatic noise in local accumulation data.

We conclude that the common climatic signal in an average stake accumulation time series is related to regional-scale circulation and is captured by the ECHAM5-wiso simulation. The lack of correlation between the S1C1 accumulation record and both stake records and ECHAM5-wiso precipitation outputs may therefore reflect local non-climatic noise.

\subsection{Processes causing non-climatic noise}

The significant correlation between the ECHAM5-wiso precipitation and the stake average accumulation record stresses the fact that the interannual variability of the average accumulation is dominated by large-scale atmospheric circulation controls on precipitation. Given the spatio-temporal variability of accumulation reported previously, we could not use accumulation information to refine the initial $\mathrm{S} 1 \mathrm{C} 1$ chronology and conclude that the $\mathrm{S} 1 \mathrm{C} 1$ accumulation record is probably heavily affected by non-climatic noise. The significant correlation between the ECHAM5-wiso precipitation and the stake average accumulation record stresses the fact that the interannual variability of the average accumulation is dominated by large-scale atmospheric circulation controls on precipitation. However, snow accumulation is spatially variable at the study site (Agosta et al., 2012). Indeed, 
Table 4. Linear relationships between temperature and $\delta^{18} \mathrm{O}$, showing the slope, the coefficient correlation and the $p$ value. The indices associated with $\mathrm{S} 1 \mathrm{C} 1$ indicate the chronology (1, initial; 2, revised).

\begin{tabular}{lllrrrr}
\hline Period & Resolution & Source of the temperature & Source of the $\delta^{18} \mathrm{O}$ & Slope & $r$ & $p$ \\
\hline $1956-2006$ & annual & READER database & $\mathrm{S} 1 \mathrm{C} 1,1$ & -0.33 & -0.13 & 0.35 \\
& & READER database & $\mathrm{S} 1 \mathrm{C} 1,2$ & 0.36 & 0.15 & 0.30 \\
& \multirow{2}{*}{ decadal } & READER database & $\mathrm{S} 1 \mathrm{C} 1,1$ & 1.49 & 0.72 & $2.6 \times 10^{-9}$ \\
& & READER database & $\mathrm{S} 1 \mathrm{C} 1,2$ & 1.32 & 0.60 & $3.2 \times 10^{-6}$ \\
\hline \multirow{2}{*}{$1979-2006$} & annual & READER database & $\mathrm{S} 1 \mathrm{C} 1,1$ & -0.33 & -0.15 & 0.44 \\
& & READER database & $\mathrm{S} 1 \mathrm{C} 1,2$ & 0.77 & 0.31 & 0.11 \\
& \multirow{2}{*}{ decadal } & READER database & $\mathrm{S} 1 \mathrm{C} 1,1$ & 1.82 & 0.72 & $1.30 \times 10^{-5}$ \\
& & READER database & $\mathrm{S} 1 \mathrm{C} 1,2$ & 1.38 & 0.51 & $5.7 \times 10^{-3}$ \\
& annual & ECHAM & $\mathrm{ECHAM}$ & 0.29 & 0.39 & 0.038 \\
& decadal & ECHAM & $\mathrm{ECHAM}$ & 0.63 & 0.80 & $4.0 \times 10^{-7}$ \\
& annual & READER database & ECHAM & 0.42 & 0.48 & 0.010 \\
& decadal & READER database & ECHAM & 0.98 & 0.89 & $3.6 \times 10^{-10}$ \\
& annual & ECHAM & $\mathrm{S} 1 \mathrm{C} 1,1$ & -0.37 & -0.17 & 0.40 \\
& annual & ECHAM & $\mathrm{S} 1 \mathrm{C} 1,2$ & 0.58 & 0.27 & 0.16 \\
\hline
\end{tabular}

the mean accumulation given by the stake located at D10 is $25.6 \mathrm{~cm}$ w.e. $\mathrm{yr}^{-1}$ and the standard deviation of mean accumulation values from the 14 stakes located within the first $10 \mathrm{~km}$ is $12.0 \mathrm{~cm}$ w.e. $\mathrm{yr}^{-1}$. A high variability reaching tens of millimetres over few metres was also reported by Genthon et al. (2007) and Favier et al. (2011) over an ablation site located $4 \mathrm{~km}$ from D10.

This high variability can be associated with wind erosion, wind redistribution, sublimation, occurrence of gravity waves in the katabatic flow and other processes during or after the precipitation event (Eisen et al., 2008). This leads to very high variability even at very small spatial scales, down to decametre scale (Libois et al., 2014), as reflected by the presence of sastrugi (Amory et al., 2015). Local features associated either with the distribution of precipitation or with wind-driven post-deposition erosion or deposition appear dominant for a given stake record, and for the S1C1 record as well.

Liquid precipitation or melting and subsequent refreezing appear to be of secondary importance in this region. Indeed, $2.5 \mathrm{~m}$ snow cores were collected every $0.5 \mathrm{~km}$ from the $156 \mathrm{~km}$ stake network of the Glacioclim observatory. These shallow cores were used for density measurements and screened for stratigraphic analysis. Small ice layers exceeding $2 \mathrm{~mm}$ were identified at the same depth. Near D10, one liquid precipitation event followed by refreezing was observed between 31 December 2014 and 1 January 2014. This single event led to ice layers reaching a thickness of up to $6 \mathrm{~cm}$. According to meteorological monitoring carried out at the Météo France DDU station, this is the only such occurrence of a heavy liquid precipitation event since 1957. From stratigraphic analyses of pits and shallow ice cores at D10 spanning the last 10 years (prior to 2014), only one ice layer thicker than $3 \mathrm{~mm}$ was identified: a $3 \mathrm{~cm}$-thick ice layer was observed at $60 \mathrm{~cm}$ depth in the surface core collected in 2008-2009. There is therefore evidence for the rare occurrence of liquid precipitation and very limited melting and refreezing of surface snow at D10, with limited percolation effects, when compared to annual accumulation amounts.

Differences in accumulation estimates from the stake data and from S1C1 may also arise from variations in surface snow density. Indeed, stake height measurements were converted into water equivalent using a spatial estimate of mean density distribution (Agosta et al., 2012). Lastly, this analysis also highlights the limited information which can be extracted from one single ice core. In the future, obtaining several ice cores from this sector will help to quantify the common climatic signal and better characterise the non-climatic noise. It will also to confirm our hypothesis that there is a significant climatic signal from this single core, as suggested by the comparison of the average stake area record with the ECHAM5-wiso output.

\section{$4.4 \quad \delta^{18}$ O-temperature relationship}

We now report the various estimates of the $\delta^{18} \mathrm{O}$-temperature relationship based on our $\mathrm{S} 1 \mathrm{C} 1$ record, instrumental temperature data and ECHAM5-wiso outputs (Table 4).

Correlations and slopes in the $\delta^{18} \mathrm{O}$-temperature relationship from the data (both chronologies) over the whole available period (1956-2006) are not significant at the annual scale contrary to the decadal scale. It suggests that the $\delta^{18} \mathrm{O}$-temperature is not stationary through time. This may arise from non-climatic noise at the interannual scale. Moreover, the decadal slopes are stronger than expected from a Rayleigh distillation, possibly resulting from either a decoupling between surface and condensation temperature or from changes in moisture sources through time. 

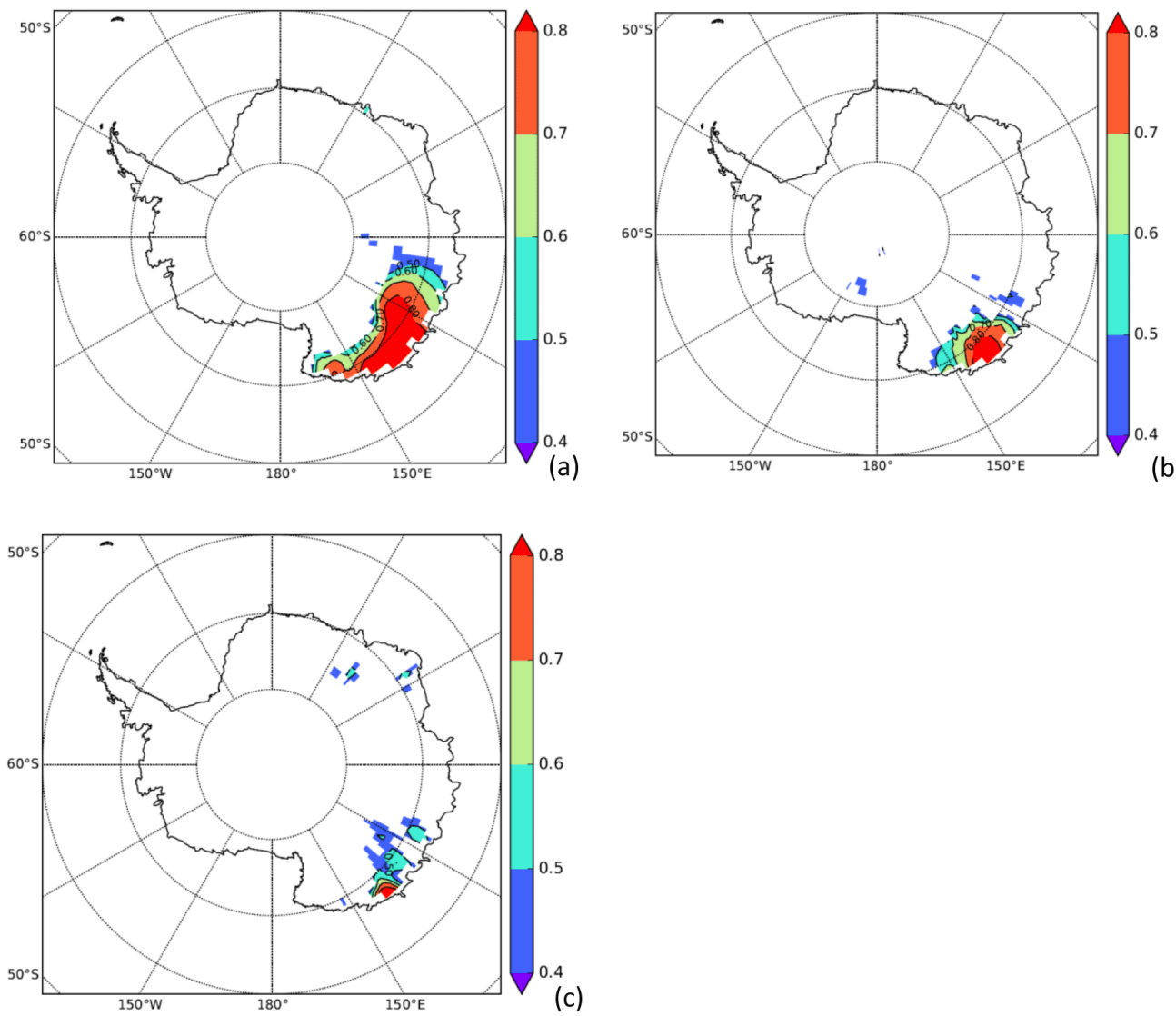

Figure 9. Correlation between simulated annual mean $2 \mathrm{~m}$ temperature (a), annual precipitation amount (b) and precipitation annual mean $\delta^{18} \mathrm{O}(\mathbf{c})$ at the $\mathrm{S} 1 \mathrm{C} 1$ site with the same variable at each grid point of the ECHAM5-wiso model for $r>0.4$ and $p<0.03$. Only significant values are represented $(p<0.05)$.

We note that over the period 1979-2006, although the $\delta^{18} \mathrm{O}$-temperature relationship from the first chronology is not significant, the relationship from the second one is significant but weak, with a slope close to the Rayleigh distillation.

The ECHAM5-wiso simulation (Sect. 2.3.1) shows that the seasonal cycle of $\delta^{18} \mathrm{O}$ is not in phase with the seasonal cycle of temperature. Moreover, the interannual variability of $\delta^{18} \mathrm{O}$ simulated in the $\mathrm{S} 1 \mathrm{C} 1$ area is maximum in local spring (November), in contrast to the maximum interannual variability of DDU temperature occurring in winter. These findings are also different from Dome $\mathrm{C}$ precipitation data (Stenni et al., 2016), showing a larger interannual variability of both temperature and $\delta^{18} \mathrm{O}$ during local winter (possibly due to variability in the frequency of maritime air mass intrusions). These model results suggest that processes other than local temperature play a key role in local $\delta^{18} \mathrm{O}$ seasonal cycle and interannual variability, as suggested by Schlosser et al. (2016).

In the ECHAM5-wiso model, the $\delta^{18} \mathrm{O}$-temperature relationship is significant (but weak) at the annual scale and therefore stronger than observed from the S1C1 record. At the decadal scale, as in the data, the correlation is higher.
However, the slope is lower (0.63) than in the data, being closer to the Rayleigh distillation. To understand this mismatch between data and simulations, we investigated alternative approaches for the $\delta^{18} \mathrm{O}$-temperature relationship obtained using annual data through the combination of temperature extracted from the READER database and simulated $\delta^{18} \mathrm{O}$, and the temperature extracted from the ECHAM5-wiso model and $\mathrm{S} 1 \mathrm{C} 1 \delta^{18} \mathrm{O}$ record (Table 4).

We found a high and significant correlation between interannual variations in temperature from the READER database and ECHAM5-wiso simulated near-surface air temperature $\left(r=0.91\right.$ and $\left.p=2.2 \times 10^{-12}\right)$ but no significant correlation between interannual variations in $\delta^{18} \mathrm{O}$ from the $\mathrm{S} 1 \mathrm{C} 1$ core (from the first dating) and simulated by ECHAM5-wiso. The variance of the ECHAM5-wiso model result is about twice as small as in the $\mathrm{S} 1 \mathrm{C} 1$ core (interannual standard deviation $0.6 \%$ for the ECHAM5-wiso model and $1.8 \%$ in the S1C1 core respectively for the period 1979-2006) (Table 2). Also, note that the strength of the correlation coefficient and the magnitude of the slope are higher for ECHAM $\delta^{18} \mathrm{O}$ versus the READER temperature than within ECHAM outputs for both annual and decadal timescales. This could be explained 
by a near-surface temperature that is closer to the condensation temperature in the case of READER than for ECHAM.

So far, we cannot conclude on the cause of such a difference in variance: the ice-core record may be affected by postdeposition features that generate noise (Sect. 4.3), or the atmospheric model may not adequately resolve moisture transport pathways driving variability in the precipitation signal. Systematic comparisons between ECHAM5-wiso and results from direct precipitation sampling or from surface water vapour isotopic composition monitoring are needed to understand whether this mismatch arises from the atmospheric model or from signal-to-noise issues in one individual icecore record. So far, no such measurements are available in Adélie Land. This finding calls for a cautious use of simulated $\delta^{18} \mathrm{O}$-temperature relationships in coastal areas, before a full assessment of the model skills can be achieved.

\subsection{Spatial extent of the representativeness of S1C1 site}

We finally take advantage of the ECHAM5-wiso simulation in order to investigate the spatial relevance of the S1C1 site. For this purpose, we calculated the correlation coefficients of the annual surface air temperature, precipitation amount and $\delta^{18} \mathrm{O}$ between the model output at the S1C1 site and the model outputs for every other Antarctic grid point (see Fig. 9). Regarding temperature, S1C1 temperature appears closely related $(r \geq 0.8)$ to regional temperature in an approximative $\sim 1000 \mathrm{~km}$ from $\sim 120$ to $150^{\circ} \mathrm{E}$. S1C1 is strongly correlated with the amount of regional precipitation, although for a much reduced area close to S1C1, within $\sim 500 \mathrm{~km}$. In the model world, S1C1 precipitation-weighted $\delta^{18} \mathrm{O}$ appears to be only related to regional signals, with the strongest correlation coefficients for a very local area (approximatively $100 \mathrm{~km}$ width).

\section{Conclusions and perspectives}

Documenting interannual climatic variations in coastal Antarctica is important to characterise natural climate variability, and provide a long-term context for recent changes beyond the instrumental period. The study of the S1C1 core addresses this challenge.

The initial chronology of the S1C1 ice core was established combining multi-parameter annual layer counting using major ions and $\delta^{18} \mathrm{O}$, as well as references horizons (nuclear test horizons and fingerprints of summers with no seaice retreat). The latter approach would not have been feasible without the knowledge provided by long-term aerosol monitoring at DDU. The S1C1 records encompass the period 1946-2006 with equivocal identification of 8 annual years.

The mean accumulation rate estimated from the S1C1 record is coherent with information from stake area measurements in Adélie Land. No long-term trend is detected in the stake data (Agosta et al., 2012) and in the S1C1 accumulation record. This robust finding challenges a recent regional modelling study showing a decrease of accumulation in coastal Adélie Land from 1979 to 2010 (Lenaerts et al., 2012). We are not confident in the signal of higher accumulation rates in the 2000s, because no such signal is detected in the comparison of recent and historical stake measurements. The average stake area record is significantly correlated with results from the ECHAM5-wiso model, but not with the S1C1 record. This finding may arise from post-deposition noise associated with, e.g. wind scouring. The lack of similarity between the S1C1 ice-core records and the stake measurements may also arise from the fact that the location of stake measurements may have moved through time (Agosta et al., 2012), and because the correction of height measurements used an average density value along the profile rather than simultaneous measurements of density, which were not available.

The $\mathrm{S} 1 \mathrm{C} 1 \delta^{18} \mathrm{O}$ record shows a remarkably small amplitude of the seasonal cycle, when compared to other isotopic datasets from coastal East Antarctica. But note that the accumulation rate is site dependent. We have stressed that remarkable years in $\delta^{18} \mathrm{O}$ and accumulation records do not coincide. Both records display a multi-decadal variability. The $\mathrm{S} 1 \mathrm{C} 1 \delta^{18} \mathrm{O}$ record is significantly correlated with DDU near-surface air temperature only at the decadal scale, with a particularly large slope. We showed that the ECHAM5wiso model strongly underestimates the interannual variability in $\delta^{18} \mathrm{O}$. This features calls for a systematic assessment of the skills of the isotopically enabled atmospheric general circulation models against the whole variety of data regarding the temporal variability. In order to better understand the drivers of isotopic variability in coastal Adélie Land, obtaining continuous vapour and precipitation isotopic composition measurements at DDU will offer the possibility of a direct comparison with atmospheric transport pathways, and with aerosol chemical data.

Implementing stable water isotopes in the regional MAR model is underway. Resolving regional aspects of the atmospheric circulation, especially related to katabatic winds and boundary layer dynamics, may indeed be important to resolve changes in moisture origin at the interannual scale. Contrary to the regional MAR model, the ECHAM5-wiso model captures interannual variations in Adélie Land accumulation rate (as inferred from the average stake measurements) and remarkable $\delta^{18} \mathrm{O}$ anomalies (as identified in the S1C1 record). Therefore, these variations are driven by largescale atmospheric circulation. We have highlighted the fact that model outputs cannot be used in a climate sense prior to 1979 , probably due to the lack of sea-ice data used in the assimilation systems.

In this paper, we have also used the ECHAM5-wiso model outputs to challenge our initial ice-core chronology. None of our key conclusions are affected by the alternative chronology implying a 2-year shift. Finally, we have used the ECHAM5-wiso model to explore the spatial relevance of precipitation and precipitation $\delta^{18} \mathrm{O}$ outputs at the $\mathrm{S} 1 \mathrm{C} 1$ site, 
and stressed the differences between a large-scale representativeness of temperature (typically, $1000 \mathrm{~km}$ ), and a smallerscale representativeness of $\delta^{18} \mathrm{O}$ (typically, $100 \mathrm{~km}$ around the S1C1 site). In the future, obtaining a network of shallow ice-core records in coastal East Antarctica will be critical to assess signal-to-noise aspects and test the validity of these findings. Obtaining longer records will also allow for a better characterisation of the multi-decadal variability and assessment of past changes in Antarctic temperature (Jones et al., 2016; PAGES 2k Consortium, 2013). Moreover, characterising spatio-temporal variations in deuterium excess will provide a complementary line of information, for the identification of seasonal variations, and for assessing past changes in moisture origin.

Further investigations are finally needed to explore the relationships between large-scale modes of variability such as the Southern Annular Mode (SAM), the Pacific - South American patterns (PSA), ENSO and climate variability in the Adélie Land sector. Indeed, composite analyses performed from 1979 to 2013 show significant imprints of SAM and PSA2 (associated with the tropical heating anomalies in the Pacific) on DDU temperature (Marshall and Thompson, 2016), and of La Niña on the coastal East Antarctic climate (Welhouse et al., 2016). No significant relationships emerge with our S1C1 records.

Our records, available as far as back as 1946 (therefore 10 years earlier than the instrumental temperature series from DDU) depict decadal variations with a $\delta^{18} \mathrm{O}$ minimum in the mid-1950s, within the range of subsequent variability. Altogether, these results imply no major climatic reorganisation in this sector of East Antarctica prior to the 1970s. It contradicts suggestions for dramatic sea-ice contraction in the mid-1950s, based on whaling ship records (Cotte and Guinet, 2007; William, 1997). Given discussions with respect to drivers of penguin demography (Raymond et al., 2015; Southwell et al., 2015), reconciling all sources of information for Adélie Land climate variability prior to the 1970s remains to be achieved.

\section{Data availability}

Ice core data can be made available for scientific purposes upon request to $S$. Preunkert.

\section{The Supplement related to this article is available online at doi:10.5194/tc-11-343-2017-supplement.}

Author contributions. V. Favier compared the accumulation data from the $\mathrm{S} 1 \mathrm{C} 1$ ice core with surface accumulation data from stake measurements and designed Fig. 1b. M. Fily and O. Magand participated in the TASTE-IDEA/VANISH 2006-2007 summer campaign, and processed density and radionucleides measurements. S.
Preunkert carried out the chemical measurements, with support from B. Jourdain. M. Legrand provided insights on aerosol signals and layer counting. B. Minster took the isotopic measurements. V. Masson-Delmotte designed the study and supervised the analyses of the records. M. Werner performed the simulation of the ECHAM5-wiso model while H. Gallée performed the simulation of the MAR model. S. Goursaud dated the S1C1 ice core and wrote the manuscript with contributions from all co-authors.

Acknowledgements. This work and the $\mathrm{PhD}$ thesis of S. Goursaud are funded by the ASUMA project and supported by the ANR (Agence Nationale de la Recherche, Project no.: ANR-14CE01-0001). The S1C1 core was drilled within the International TASTE-IDEA (Trans-Antarctic Scientific Traverse Expeditions Ice Divide of East Antarctica)/VANISH (Vulnaribility of ANtarctic Ice SHeet and its atmosphere) programmes supported by the ANR (Agence Nationale de la Recherche, Project no.: ANR-07-VULN0013), during the 2006/2007 summer campaign, with logistical support from Institut Polaire Français-Paul Emile Victor (IPEV). Chemical analysis were supported by the French environmental observation service CESOA (Etude du cycle atmosphérique du Soufre en relation avec le climat aux moyennes et hautes latitudes Sud, http://www-lgge.ujf-grenoble.fr/CESOA/rubri-que.php3?id_ rubrique $=2$ ) dedicated to the study of the sulfur cycle at middle and high southern latitudes and supported by the CNRS (INSU) and IPEV. We thank all the field team members who contributed to the success of the 2006-2007 TASTE-IDEA/VANISH summer campaign. GLACIOCLIM-SAMBA observatory is supported by IPEV and INSU. Finally, this work was first presented as a poster to the 2016 IPICS (International Partnership in Ice Core Sciences) conference in Hobart, Tasmania. We are extremely grateful to the scientific and local organisation committees for such a stimulating meeting!

Edited by: M. van den Broeke

Reviewed by: B. Stenni and E. Isaksson

\section{References}

Agosta, C., Favier, V., Genthon, C., Gallée, H., Krinner, G., Lenaerts, J. T., and van den Broeke, M. R.: A 40-year accumulation dataset for Adelie Land, Antarctica and its application for model validation, Clim. Dynam., 38, 75-86, 2012.

Agosta, C., Favier, V., Krinner, G., Gallée, H., Fettweis, X., and Genthon, C.: High-resolution modelling of the Antarctic surface mass balance, application for the twentieth, twenty first and twenty second centuries, Clim. Dynam., 41, 3247-3260, 2013.

Amory, C., Trouvilliez, A., Gallée, H., Favier, V., Naaim-Bouvet, F., Genthon, C., Agosta, C., Piard, L., and Bellot, H.: Comparison between observed and simulated aeolian snow mass fluxes in Adélie Land, East Antarctica, The Cryosphere, 9, 1373-1383, doi:10.5194/tc-9-1373-2015, 2015.

Bintanja, R.: Snowdrift suspension and atmospheric turbulence. Part I: Theoretical background and model description, Bound.Lay. Meteorol., 95, 343-368, 2000.

Casado, M., Landais, A., Masson-Delmotte, V., Genthon, C., Kerstel, E., Kassi, S., Arnaud, L., Picard, G., Prie, F., Cattani, O., 
Steen-Larsen, H.-C., Vignon, E., and Cermak, P.: Continuous measurements of isotopic composition of water vapour on the East Antarctic Plateau, Atmos. Chem. Phys., 16, 8521-8538, doi:10.5194/acp-16-8521-2016, 2016.

Center, E.: Sea ice concentrations from Nimbus-7 SMMR and DMSP SSM/I passive microwave data, 1996.

Church, J. A., Clark, P. U., Cazenave, A., Gregory, J. M., Jevrejeva, S., Levermann, A., Merrifield, M. A., Milne, G. A., Nerem, R. S., and Nunn, P. D.: Sea level change, PM Cambridge University Press, 2013.

Cotte, C. and Guinet, C.: Historical whaling records reveal major regional retreat of Antarctic sea ice, Deep-Sea Res. Pt. I, 54, 243 252, 2007.

Dee, D., Uppala, S., Simmons, A., Berrisford, P., Poli, P., Kobayashi, S., Andrae, U., Balmaseda, M., Balsamo, G., and Bauer, P.: The ERA-Interim reanalysis: Configuration and performance of the data assimilation system, Q. J. Roy. Meteor. Soc., 137, 553-597, 2011.

Delmas, R. and Pourchet, M.: Utilisation de filtres échangeurs d'ions pour l'étude de l'activité globale d'un carottage glaciologique, International Association of Hydrological Sciences Publication, 118, 159-163, 1977.

Eisen, O., Frezzotti, M., Genthon, C., Isaksson, E., Magand, O., Van Den Broeke, M. R., Dixon, D. A., Ekaykin, A., Holmlund, P., and Kameda, T.: Ground-based measurements of spatial and temporal variability of snow accumulation in East Antarctica, Rev. Geophys., 46, doi:10.1029/2006RG000218, 2008.

Favier, V., Agosta, C., Genthon, C., Arnaud, L., Trouvillez, A., and Gallée, H.: Modeling the mass and surface heat budgets in a coastal blue ice area of Adelie Land, Antarctica, J. Geophys. Res.-Earth, 116, doi:10.1029/2010JF001939, 2011.

Favier, V., Agosta, C., Parouty, S., Durand, G., Delaygue, G., Gallée, H., Drouet, A.-S., Trouvilliez, A., and Krinner, G.: An updated and quality controlled surface mass balance dataset for Antarctica, The Cryosphere, 7, 583-597, doi:10.5194/tc-7-5832013, 2013.

Frezzotti, M., Urbini, S., Proposito, M., Scarchilli, C., and Gandolfi, S.: Spatial and temporal variability of surface mass balance near Talos Dome, East Antarctica, J. Geophys. Res.-Earth, 112, doi:10.1029/2006JF000638, 2007.

Fujita, K. and Abe, O.: Stable isotopes in daily precipitation at Dome Fuji, East Antarctica, Geophys. Res. Lett., 33, doi:10.1029/2006GL026936, 2006.

Gallée, H.: Simulation of the mesocyclonic activity in the Ross Sea, Antarctica, Mon. Weather Rev., 123, 2051-2069, 1995.

Gallée, H. and Schayes, G.: Development of a three-dimensional meso- $\gamma$ primitive equation model: katabatic winds simulation in the area of Terra Nova Bay, Antarctica, Mon. Weather Rev., 122, 671-685, 1994.

Gallée, H., Guyomarc'h, G., and Brun, E.: Impact of snow drift on the Antarctic ice sheet surface mass balance: possible sensitivity to snow-surface properties, Bound.-Lay. Meteorol., 99, 1-19, 2001.

Gallée, H., Trouvilliez, A., Agosta, C., Genthon, C., Favier, V., and Naaim-Bouvet, F.: Transport of snow by the wind: a comparison between Observations in Adélie Land, Antarctica, and Simulations made with the Regional Climate Model MAR, Bound.-Lay. Meteorol., 146, 133-147, 2013.
Genthon, C., Lardeux, P., and Krinner, G.: The surface accumulation and ablation of a coastal blue-ice area near Cap Prudhomme, Terre Adélie, Antarctica, J. Glaciol., 53, 635-645, 2007.

Ginot, P., Stampfli, F., Stampfli, D., Schwikowski, M., and Gaggeler, H.: FELICS, a new ice core drilling system for highaltitude glaciers, Memoirs of National Institute of Polar Research, 56, 38-48, 2002.

Graf, W., Reinwarth, O., Moser, H., Minikin, A., Wagenbach, D., Kipfstuhl, J., and Oerter, H.: Isotopic and chemical investigations of $10 \mathrm{~m}$ firn cores from the eastern part of the Ronne Ice Shelf, Antarctica, FRISP Rep, 5, 45-53, 1991.

Hoffmann, G., Werner, M., and Heimann, M.: Water isotope module of the ECHAM atmospheric general circulation model: A study on timescales from days to several years, J. Geophys. Res.Atmos., 103, 16871-16896, 1998.

Johnsen, S.: Stable isotope homogenization of polar firn and ice, Isotopes and impurities in snow and ice, 1, 210-219, 1977.

Jones, D. A. and Simmonds, I.: Time and space spectral analyses of Southern Hemisphere sea level pressure variability, Mon. Weather Rev., 121, 661-672, 1993.

Jones, J. M., Gille, S. T., Goosse, H., Abram, N. J., Canziani, P. O., Charman, D. J., Clem, K. R., Crosta, X., de Lavergne, C., and Eisenman, I.: Assessing recent trends in high-latitude Southern Hemisphere surface climate, Nature Climate Change, 6, 917926, 2016.

Jourdain, B. and Legrand, M.: Year-round records of bulk and sizesegregated aerosol composition and $\mathrm{HCl}$ and $\mathrm{HNO}_{3}$ levels in the Dumont d'Urville (coastal Antarctica) atmosphere: Implications for sea-salt aerosol fractionation in the winter and summer, $\mathrm{J}$ Geophys. Res.-Atmos., 107, doi:10.1029/2002JD002471, 2002.

Kessler, E.: On the distribution and continuity of water substance in atmospheric circulation, 10, 88 pp., 1969.

König-Langlo, G., King, J., and Pettré, P.: Climatology of the three coastal Antarctic stations Dumont d'Urville, Neumayer, and Halley, J. Geophys. Res.-Atmos., 103, 10935-10946, 1998.

Korona, J., Berthier, E., Bernard, M., Rémy, F., and Thouvenot, E.: SPIRIT. SPOT 5 stereoscopic survey of polar ice: reference images and topographies during the fourth International Polar Year (2007-2009), Int. Soc. Photogramme., 64, 204-212, 2009.

Krinner, G., Magand, O., Simmonds, I., Genthon, C., and Dufresne, J.-L.: Simulated Antarctic precipitation and surface mass balance at the end of the twentieth and twenty-first centuries, Clim. Dynam., 28, 215-230, 2007.

Landais, A., Ekaykin, A., Barkan, E., Winkler, R., and Luz, B.: Seasonal variations of ${ }^{17} \mathrm{O}$-excess and d-excess in snow precipitation at Vostok station, East Antarctica, J. Glaciol., 58, 725-733, 2012.

Legrand, M. and Wagenbach, D.: Impact of the Cerro Hudson and Pinatubo volcanic eruptions on the Antarctic air and snow chemistry, J. Geophys. Res.-Atmos., 104, 1581-1596, 1999.

Legrand, M., Ducroz, F., Wagenbach, D., Mulvaney, R., and Hall, J.: Ammonium in coastal Antarctic aerosol and snow: Role of polar ocean and penguin emissions, J. Geophys. Res.-Atmos., 103, 11043-11056, 1998.

Legrand, M., Yang, X., Preunkert, S., and Theys, N.: Year-round records of sea salt, gaseous, and particulate inorganic bromine in the atmospheric boundary layer at coastal (Dumont d'Urville) and central (Concordia) East Antarctic sites, J. Geophys. Res.Atmos., 121, 997-1023, 2016. 
Lenaerts, J., Den Broeke, M., Berg, W., Meijgaard, E. V., and Kuipers Munneke, P.: A new, high-resolution surface mass balance map of Antarctica (1979-2010) based on regional atmospheric climate modeling, Geophys. Res. Lett., 39, doi:10.1029/2011GL050713, 2012.

Levkov, L., Rockel, B., Kapitza, H., and Raschke, E.: 3D mesoscale numerical studies of cirrus and stratus clouds by their time and space evolution, Contributions to Atmospheric Physics, 65, 3558, 1992.

Libois, Q., Picard, G., Arnaud, L., Morin, S., and Brun, E.: Modeling the impact of snow drift on the decameter-scale variability of snow properties on the Antarctic Plateau, J. Geophys. Res.Atmos., 119, doi:10.1002/2014JD022361, 2014.

Lin, Y.-L., Farley, R. D., and Orville, H. D.: Bulk parameterization of the snow field in a cloud model, J. Climate Appl. Meteorol., 22, 1065-1092, 1983.

Magand, O.: Bilan de masse de surface Antarctique: techniques de mesure et analyse critique, Doctoral dissertation, Université Joseph Fourier, 2009.

Marshall, G. J. and Thompson, D. W.: The signatures of large-scale patterns of atmospheric variability in Antarctic surface temperatures, J. Geophys. Res.-Atmos., 121, 3276-3289, 2016.

Masson-Delmotte, V., Delmotte, M., Morgan, V., Etheridge, D., Van Ommen, T., Tartarin, S., and Hoffmann, G.: Recent southern Indian Ocean climate variability inferred from a Law Dome ice core: New insights for the interpretation of coastal Antarctic isotopic records, Clim. Dynam., 21, 153-166, 2003.

Masson-Delmotte, V., Hou, S., Ekaykin, A., Jouzel, J., Aristarain, A., Bernardo, R., Bromwich, D., Cattani, O., Delmotte, M., Falourd, S., Frezzotti, M., Gallée, H., Genoni, L., Isaksson, E., Landais, A., Helsen, M., Hoffmann, G., Lopez, J., Morgan, V., Motoyama, H., Noone, D., Oerter, H., Petit, J.-R., Royer, A., Uemura, R., Schmidt, G., Schlosser, E., Simões, J., Steig, E. J., Stenni, B., Stievenard, M., Van den Broeke, M. R., Van De Wal, R. S., Van de Berg, W., Vimeux, F., and White, J. W.: A review of Antarctic surface snow isotopic composition: observations, atmospheric circulation, and isotopic modeling, J. Climate, 21, 3359-3387, 2008.

Masson-Delmotte, V., Steen-Larsen, H. C., Ortega, P., Swingedouw, D., Popp, T., Vinther, B. M., Oerter, H., Sveinbjornsdottir, A. E., Gudlaugsdottir, H., Box, J. E., Falourd, S., Fettweis, X., Gallée, H., Garnier, E., Gkinis, V., Jouzel, J., Landais, A., Minster, B., Paradis, N., Orsi, A., Risi, C., Werner, M., and White, J. W. C.: Recent changes in north-west Greenland climate documented by NEEM shallow ice core data and simulations, and implications for past-temperature reconstructions, The Cryosphere, 9, 14811504, doi:10.5194/tc-9-1481-2015, 2015.

Meyers, M. P., DeMott, P. J., and Cotton, W. R.: New primary icenucleation parameterizations in an explicit cloud model, J. Appl. Meteorol., 31, 708-721, 1992.

Minikin, A., Legrand, M., Hall, J., Wagenbach, D., Kleefeld, C., Wolff, E., Pasteur, E. C., and Ducroz, F.: Sulfur-containing species (sulfate and methanesulfonate) in coastal Antarctic aerosol and precipitation, J. Geophys. Res.-Atmos., 103, 1097510990, 1998.

Morcrette, J.-J.: Assessment of the ECMWF model cloudiness and surface radiation fields at the ARM SGP site, Mon. Weather Rev., 130, 257-277, 2002.
Mulvaney, R., Wagenbach, D., and Wolff, E.: Postdepositional change in snowpack nitrate from observation of year-round near-surface snow in coastal Antarctica, J. Geophys. Res., 103, 11021-11031, 1998.

Mulvaney, R., Oerter, H., Peel, D. A., Graf, W., Arrowsmith, C., Pasteur, E. C., Knight, B., Littot, G. C., and Miners, W. D. 1000 year ice-core records from Berkner Island, Antarctica, Ann. Glaciol., 35, 45-51, 2002.

PAGES 2k Consortium: Continental-scale temperature variability during the past two millennia, Nat. Geosci., 6, 339e346, 2013.

Paillard, D., Labeyrie, L., and Yiou, P.: Macintosh program performs time-series analysis, Eos, Transactions American Geophysical Union, 77, 379-379, 1996.

Palerme, C., Genthon, C., Claud, C., Kay, J. E., Wood, N. B., and L'Ecuyer, T.: Evaluation of current and projected Antarctic precipitation in CMIP5 models, Clim. Dynam., 2016, 1-15, 2016.

Périard, C. and Pettré, P.: Some aspects of the climatology of dumont D'Irville, adélie land, Antarctica, Int. J. Climatol., 13, 313 328, 1993.

Picciotto, E. A. and Wilgain, S.: Fission products in Antarctic snow, a reference level for measuring accumulation, J. Geophys. Res., 68, 5965-5972, 1963.

Preunkert, S. and Legrand, M.: Towards a quasi-complete reconstruction of past atmospheric aerosol load and composition (organic and inorganic) over Europe since 1920 inferred from Alpine ice cores, Clim. Past, 9, 1403-1416, doi:10.5194/cp-91403-2013, 2013.

Raymond, B., Lea, M. A., Patterson, T., Andrews-Goff, V., Sharples, R., Charrassin, J. B., Cottin, M., Emmerson, L., Gales, N., and Gales, R.: Important marine habitat off east Antarctica revealed by two decades of multi-species predator tracking, Ecography, 38, 121-129, 2015.

Ritter, F., Steen-Larsen, H. C., Werner, M., Masson-Delmotte, V., Orsi, A., Behrens, M., Birnbaum, G., Freitag, J., Risi, C., and Kipfstuhl, S.: Isotopic exchange on the diurnal scale between near-surface snow and lower atmospheric water vapor at Kohnen station, East Antarctica, The Cryosphere, 10, $1647-$ 1663, doi:10.5194/tc-10-1647-2016, 2016.

Roeckner, E., Bäuml, G., Bonaventura, L., Brokopf, R., Esch, M., Giorgetta, M., Hagemann, S., Kirchner, I., Kornblueh, L., and Manzini, E.: The atmospheric general circulation model ECHAM 5. PART I: Model description, Report/MPI für Meteorologie, 349, 2003.

Schlosser, E., Oerter, H., Masson-Delmotte, V., and Reijmer, C.: Atmospheric influence on the deuterium excess signal in polar firn: implications for ice-core interpretation, J. Glaciol., 54, 117 124, 2008.

Schlosser, E., Stenni, B., Valt, M., Cagnati, A., Powers, J. G., Manning, K. W., Raphael, M., and Duda, M. G.: Precipitation and synoptic regime in two extreme years 2009 and 2010 at Dome C, Antarctica - implications for ice core interpretation, Atmos. Chem. Phys., 16, 4757-4770, doi:10.5194/acp-16-4757-2016, 2016.

Schmidt, G. A., LeGrande, A. N., and Hoffmann, G.: Water isotope expressions of intrinsic and forced variability in a coupled ocean-atmosphere model, J. Geophys. Res.-Atmos., 112, doi:10.1029/2006JD007781, 2007. 
Simmonds, I. and Jacka, T.: Relationships between the interannual variability of Antarctic sea ice and the Southern Oscillation, J. Climate, 8, 637-647, 1995.

Southwell, C., Emmerson, L., McKinlay, J., Newbery, K., Takahashi, A., Kato, A., Barbraud, C., DeLord, K., and Weimerskirch, H.: Spatially extensive standardized surveys reveal widespread, multi-decadal increase in East Antarctic Adélie penguin populations, PloS one, 10, e0139877, doi:10.1371/journal.pone.0165989, 2015.

Steen-Larsen, H. C., Masson-Delmotte, V., Hirabayashi, M., Winkler, R., Satow, K., Prié, F., Bayou, N., Brun, E., Cuffey, K. M., Dahl-Jensen, D., Dumont, M., Guillevic, M., Kipfstuhl, S., Landais, A., Popp, T., Risi, C., Steffen, K., Stenni, B., and Sveinbjörnsdottír, A. E.: What controls the isotopic composition of Greenland surface snow?, Clim. Past, 10, 377-392, doi:10.5194/cp-10-377-2014, 2014.

Stenni, B., Scarchilli, C., Masson-Delmotte, V., Schlosser, E., Ciardini, V., Dreossi, G., Grigioni, P., Bonazza, M., Cagnati, A., Karlicek, D., Risi, C., Udisti, R., and Valt, M.: Three-year monitoring of stable isotopes of precipitation at Concordia Station, East Antarctica, The Cryosphere, 10, 2415-2428, doi:10.5194/tc-102415-2016, 2016.

Touzeau, A., Landais, A., Stenni, B., Uemura, R., Fukui, K., Fujita, S., Guilbaud, S., Ekaykin, A., Casado, M., Barkan, E., Luz, B., Magand, O., Teste, G., Le Meur, E., Baroni, M., Savarino, J., Bourgeois, I., and Risi, C.: Acquisition of isotopic composition for surface snow in East Antarctica and the links to climatic parameters, The Cryosphere, 10, 837-852, doi:10.5194/tc-10-8372016, 2016.

Turner, J., Colwell, S. R., Marshall, G. J., Lachlan-Cope, T. A., Carleton, A. M., Jones, P. D., Lagun, V., Reid, P. A., and Iagovkina, S.: The SCAR READER project: toward a high-quality database of mean Antarctic meteorological observations, J. Climate, 17, 2890-2898, 2004.

Uppala, S. M., Kållberg, P., Simmons, A., Andrae, U., Bechtold, V. D., Fiorino, M., Gibson, J., Haseler, J., Hernandez, A., and Kelly, G.: The ERA-40 re-analysis, Q. J. Roy. Meteorol. Soc., 131, 2961-3012, 2005.

Verfaillie, D., Fily, M., Le Meur, E., Magand, O., Jourdain, B., Arnaud, L., and Favier, V.: Snow accumulation variability derived from radar and firn core data along a $600 \mathrm{~km}$ transect in Adelie Land, East Antarctic plateau, The Cryosphere, 6, 1345-1358, doi:10.5194/tc-6-1345-2012, 2012.
Wagenbach, D., Ducroz, F., Mulvaney, R., Keck, L., Minikin, A., Legrand, M., Hall, J., and Wolff, E.: Sea-salt aerosol in coastal Antarctic regions, J. Geophys. Res.-Atmos., 103, 10961-10974, 1998a.

Wagenbach, D., Legrand, M., Fischer, H., Pichlmayer, F., and Wolff, E.: Atmospheric near-surface nitrate at coastal Antarctic sites, J. Geophys. Res.-Atmos., 103, 11007-11020, 1998 b.

Wang, Y., Ding, M., van Wessem, J., Schlosser, E., Altnau, S., van den Broeke, M. R., Lenaerts, J. T., Thomas, E. R., Isaksson, E., and Wang, J.: A comparison of Antarctic Ice Sheet surface mass balance from atmospheric climate models and in situ observations, J. Climate, 29, 5317-5337, 2016.

Welhouse, L. J., Lazzara, M. A., Keller, L. M., Tripoli, G. J., and Hitchman, M. H.: Composite analysis of the effects of ENSO events on Antarctica, J. Climate, 29, 1797-1808, 2016.

Wendler, G., Stearns, C., Weidner, G., Dargaud, G., and Parish, T.: On the extraordinary katabatic winds of Adélie Land, J. Geophys. Res.-Atmos., 102, 4463-4474, 1997.

Werner, M., Heimann, M., and Hoffmann, G.: Isotopic composition and origin of polar precipitation in present and glacial climate simulations, Tellus B, 53, doi:10.1034/j.16000889.2001.01154.x, 2001.

Werner, M., Langebroek, P. M., Carlsen, T., Herold, M., and Lohmann, G.: Stable water isotopes in the ECHAM5 general circulation model: Toward high-resolution isotope modeling on a global scale, J. Geophys. Res.-Atmos., 116, doi:10.1029/2011JD015681, 2011.

William, K.: Abrupt mid-twentieth-century decline in Antarctic seaice extent from whaling records, Nature, 389, 57-60, 1997.

Wolff, E., Hall, J., Mulvaney, R., Pasteur, E., Wagenbach, D., and Legrand, M.: Relationship between chemistry of air, fresh snow and firn cores for aerosol species in coastal Antarctica, J. Geophys. Res., 103, 11057-11070, 1998.

Yuan, X. and Yonekura, E.: Decadal variability in the Southern Hemisphere, J. Geophys. Res.-Atmos., 116, doi:10.1029/2011JD015673, 2011. 